F. Goff • G. M. McMurtry • D. Counce • J. A. Simac

A. R. Roldán-Manzo • D. R. Hilton

\title{
Contrasting hydrothermal activity at Sierra Negra and Alcedo volcanoes, Galapagos Archipelago, Ecuador
}

Received: 19 April 1999 / Accepted: 23 October 1999

\begin{abstract}
Sierra Negra and Alcedo volcanoes are adjacent tholeiitic shields with summit calderas located on Isabela Island in the Galapagos Archipelago. Although basaltic eruptions have characterized the evolution of these volcanoes, Alcedo has produced minor volumes of rhyolite lavas and tephras dated at approximately $100 \mathrm{ka}$. Fumaroles and ephemeral acidsulfate seeps occur within the calderas of both volcanoes, whereas neutral-chloride and diluted steamheated hot springs are absent. Fumarolic activity inside Sierra Negra (Mina Azufral) is fault controlled along the west margin of a horst and discharge temperatures are $\leq 210^{\circ} \mathrm{C}$ (January to February 1995). Water content of the total gas is approximately $75 \mathrm{~mol} . \%$, and noncondensible gases consist of approximately $97 \mathrm{~mol} . \% \mathrm{CO}_{2}$ and approximately $85 \%$ $\mathrm{SO}_{2}$ of the total sulfur gas. Relative amounts of $\mathrm{He}$, $\mathrm{Ar}$, and $\mathrm{N}_{2}$ show a distinct hot-spot signature $\left({ }^{3} \mathrm{He} /\right.$ $\left.{ }^{4} \mathrm{He}=17.4 \pm 0.3 \mathrm{R}_{\mathrm{A}}\right)$. The $\delta^{13} \mathrm{C}-\mathrm{CO}_{2}$ is approximately $-3.6 \%$ and $\delta^{34} \mathrm{~S}_{\mathrm{T}}$ is approximately $+3.3 \%$. The $\delta \mathrm{D} /$ $\delta^{18} \mathrm{O}$ of fumarole $\mathrm{H}_{2} \mathrm{O}$ indicates steam separation from local meteoric waters whose estimated minimum
\end{abstract}

Editorial responsibility: W. Hildreth

Fraser Goff $(\bowtie) \cdot$ Dale Counce

Los Alamos National Laboratory, Los Alamos, NM 87545, USA

Gary M. McMurtry

SOEST University of Hawaii, Honolulu, HI 96822, USA

James A. Stimac

Unocal Corporation, Philippines, 14141 Southwest Freeway, Sugar Land, TX 77478, USA

Alfredo Roldán-Manzo

INDE, Guatemala City, Guatemala

David R. Hilton

Department of Earth Sciences, Vrije Universiteit, HV1081

Amsterdam, The Netherlands

Present address:

David R. Hilton, Scripps Institution of Oceanography,

La Jolla, CA 92093-0244, USA mean residence time from ${ }^{3} \mathrm{H}$ analyses is $\leq 40$ years. Fumarolic activity at Alcedo is controlled by a caldera-margin fault containing at least seven hydrothermal explosion craters, and by an intracaldera rhyolite vent. Two explosion craters which formed in 1993-1994 produce approximately $15 \mathrm{~m}^{3} / \mathrm{s}$ of steam, yet discharge temperatures are $\leq 97^{\circ} \mathrm{C}$. Water content of the total gas is $95-97 \mathrm{~mol} \%$, noncondensible gas is 92-98 mol.\% $\mathrm{CO}_{2}$, and sulfur gas is dominated by $\mathrm{H}_{2} \mathrm{~S}$. Relative amounts of $\mathrm{He}, \mathrm{Ar}$, and $\mathrm{N}_{2}$ show extensive mixing between hot spot and air or air-saturated meteoric water components but the average $>{ }^{3} \mathrm{He} /$ ${ }^{4} \mathrm{He}=15.5 \pm 0.4 \mathrm{R}_{\mathrm{A}}$. The $\delta^{13} \mathrm{C}-\mathrm{CO}_{2}$ is approximately $-3.5 \%$ and $\delta^{34} \mathrm{~S}_{\mathrm{T}}$ is approximately $-0.8 \%$. The $\delta \mathrm{D} /$ $\delta^{18} \mathrm{O}$ of fumarole steam indicates separation from a homogeneous reservoir that is enriched $3-5 \%$ in ${ }^{18} \mathrm{O}$ compared with local meteoric water. ${ }^{3} \mathrm{H}$ indicates that this reservoir water has a maximum mean residence time of approximately 400 years and empirical gas geothermometry indicates a reservoir temperature of $260-320^{\circ} \mathrm{C}$. The intracaldera hydrothermal reservoir in Alcedo is probably capable of producing up to $150 \mathrm{MW}$; however, environmental concerns as well as lack of infrastructure and power users will limit the development of this resource.

Key words Galapagos · Volcanic gases · Gas geochemistry · Isotope geochemistry $\cdot$ Geothermal systems $\cdot$ Sierra Negra $\cdot$ Alcedo

\section{Introduction}

As part of a comprehensive study on the stable isotope and tritium content of magmatic fluids (Goff and McMurtry, in press), we visited Sierra Negra and Alcedo volcanoes because they are hot-spot volcanoes with mantle affinities and are known to contain accessible fumaroles (Colony and Nordlie 1973; Delaney et al. 1973; Nordlie and Colony 1973). We wanted to determine if anomalous tritium is present in the mag- 
matic waters discharged from these volcanoes. We collected many gas and condensate samples, background waters, altered rocks, and volcanic rocks for various chemical and isotopic analyses to provide complementary data for the tritium project. Although isotopic results detected no magmatic water at either volcano (as defined below), our data show surprising differences in hydrothermal activity at the two locations. The object of this paper is to compare and contrast the geologic setting and hydrogeochemical data of these adjacent shield volcanoes. We also show that dilution of magmatic fluids by meteoric waters is a common phenomenon at basalt volcanoes.

\section{Geologic background}

The Galapagos Archipelago is a broad cluster of basaltic volcanoes that have grown during hot-spot magmatism adjacent to the Galapagos spreading center (Hey et al. 1977; Simkin 1984; T. Naumann and D. Geist, submitted). During the past million years these islands have comprised one of the most volcanically active regions on earth. Most activity is now centered at the seven shield volcanoes on Isabela and Fernandina Islands (Fig. 1). Nearly 50 eruptions have

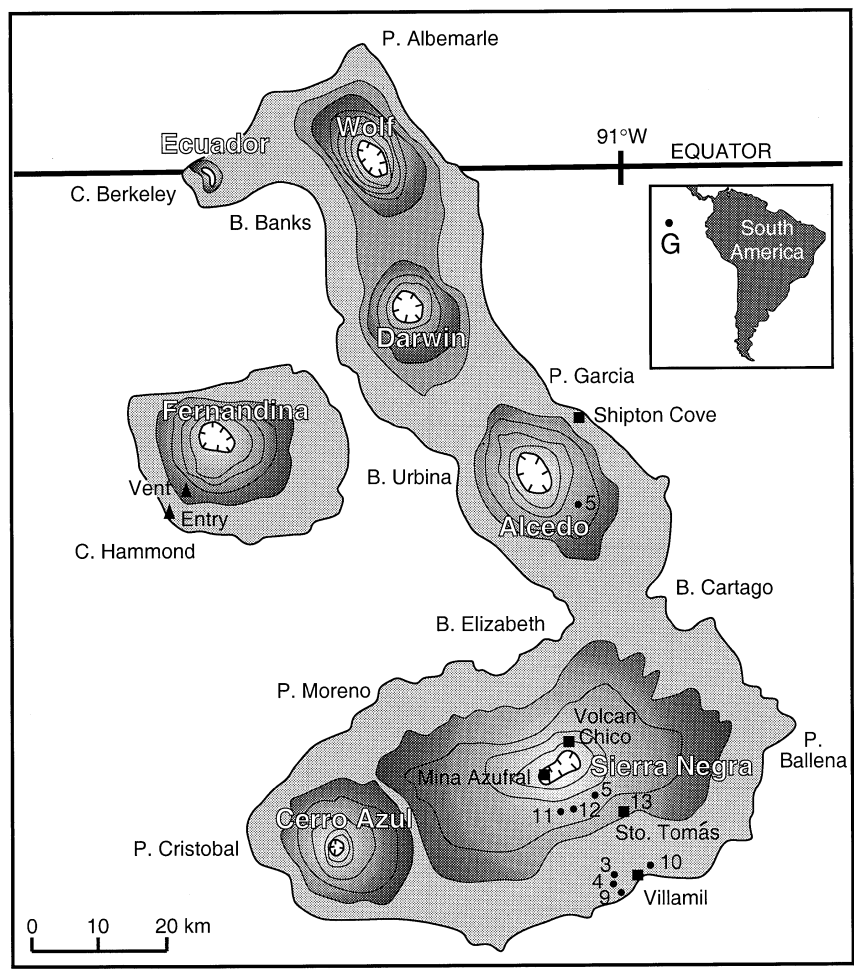

Fig. 1 Map shows locations of shield volcanoes on Isabela and Fernandina Islands, Galapagos Archipelago (contour interval is $200 \mathrm{~m}$ ). Isabela Island consists of six coalesced shield volcanoes. Hydrothermal manifestations occur at several volcanoes, although the major sites occur at Sierra Negra and Alcedo. Numbers refer to sample sites in Table 1. Other sample sites can be located from descriptions in tables and text or from the following figures. $B$ Bay; $C$ Cape; $P$ Point been observed and several unobserved eruptions have occurred in historic times (Simkin et al. 1981). A variety of chemical and isotopic arguments indicate that Galapagos magmas are generated as an undegassed deep mantle plume rises and mixes with magmas derived from relatively depleted asthenospheric mantle (White et al. 1993; Graham et al. 1993).

According to Geist et al. (1994) Isabela and Fernandina Islands also comprise a volcanic sub-province within the archipelago as defined by their distinct magma compositions and caldera morphologies. Although small volumes of oceanic rhyolite produced by fractional crystallization of basalt occur at Alcedo volcano (McBirney et al. 1985; Geist et al. 1994, 1995), other eruptive products on these two islands consist of oceanic tholeiite and tiny volumes of andesite.

Diffuse hydrothermal phenomena and fumarolic activity occur at several volcanoes throughout the archipelago (Simkin 1984). High-temperature fumaroles $\left(100-220^{\circ} \mathrm{C}\right)$ with associated sulfur deposits have been studied at the Volcan Azufre (Mina Azufral) and Volcan Chico areas of Sierra Negra volcano (Colony and Nordlie 1973; Delaney et al. 1973) and spectacular displays of water fountaining and fumarolic activity have been described from Alcedo volcano (Nordlie and Colony 1973). Geist et al. (1994) noted that much of the hydrothermal activity within Alcedo was controlled by a fault zone within the southern caldera wall and pointed out that recent tree kills indicated transient activity. Green (1994) characterized two new fumaroles that formed phreatic explosion craters along this fault zone in late 1993 to early 1994.

\section{Field observations}

\section{Sierra Negra volcano}

A detailed description of our field activities, from January to February 1995, can be obtained from the Charles Darwin Scientific Station or from the first author (F. Goff and G.M. McMurtry, unpublished data). Mina Azufral occurs at the west margin of an intracaldera horst bounded by a sinuous fault zone on the north, west, and south (Reynolds et al. 1995). The horst dips gently to the east but the western margin is a scarp nearly $200 \mathrm{~m}$ high composed of many normal faults with down-to-the-west displacements. This faulting has produced a series of relatively narrow benches above the western caldera floor or "moat" (Fig. 2a). We observed two primary clusters of fumaroles situated on the edges of fault blocks and both trending $\mathrm{N}-\mathrm{S}$ for distances of approximately $100-150 \mathrm{~m}$. Each fumarole cluster contains one dominant fumarole pit $\geq 2 \mathrm{~m}$ deep surrounded by a "sand cone" of altered basalt and other hydrothermal debris (Colony and Nordlie 1973). Gas pressures from these pit fumaroles were high enough to create "jet noise" and low foun- 
tains ( $\leq 1 \mathrm{~m}$ high) of sand but there are periods when sand is thrown out of the pits.

Copious deposits of sulfur with minor anhydrite and gypsum are the major secondary phases within the fumarole areas. The strong odor of $\mathrm{SO}_{2}$ with subordinate $\mathrm{H}_{2} \mathrm{~S}$ is like that of fumaroles from other volcanoes that degas partially or totally from magma. During our activities, fumarole temperatures were $\leq 210^{\circ} \mathrm{C}$ and the condensates had $\mathrm{pH}<2$. Although the main trend of activity is $\mathrm{N}-\mathrm{S}$, parasitic fractures of many orientations occur throughout the fumarole clusters. Delicate sulfur crystals decorate the mouths of smaller features while massive sulfur and highly altered rock occur throughout the area. Small patches of orange molten sulfur form at the periphery of some fumaroles. The host rock is a plagioclase-phyric, olivine basalt. Acid alteration has caused spheroidal exfoliation of basalt blocks at the margins of the fumarole fields. Within the fumarole fields, the basalt is completely decomposed to mixtures of smectite, kaolinite, silica, iron oxides, and the incrustations mentioned previously.

As at many other high-temperature volcanic fumarole fields, molten sulfur forms droplets, pools, and small flows around the periphery of individual fumaroles. Conditions favoring formation of molten sulfur are discussed by Colony and Nordlie (1973). Changes in near-surface thermal regime probably contribute to remelting and redeposition of sulfur. These authors also described "sulfur flows" $225 \mathrm{~m}$ long and $30 \mathrm{~m}$ wide that originate from the fumarole fields and implied that they flowed as liquid sulfur. However, examination of specimens from these long flows shows that they have fragmental textures of approximately $50 \%$ altered rock and 50\% sulfur. The samples do not have a holocrystalline appearance. Instead, the flows resemble debris-flow or mud-flow deposits, rather than molten flow deposits. We suggest that there are rare periods when so much rain falls on the fumarole mounds that the altered sands and sulfur flow as a slurry off the deposit into the caldera moat.

Minor fumarolic activity was seen along several $\mathrm{N}$-trending fissures and fractures on the bench immediately south of the main fumarole clusters. Several of these fractures are up to $3 \mathrm{~m}$ wide and appear to be incipient normal faults. Fumarole gases were too diffuse to sample and alteration was comparatively minor. The textures of columnar basalt are exposed on fissure walls.

A relatively young cinder cone occurs on the floor of the caldera just to the NW of the main fumaroles. The vent of this cone fed mostly aa lavas that flowed south into a narrow, shallow graben in the west moat (Fig. 2a). The age of this cone and lava flow postdates most of the uplift on the horst and faulting in the moat, because the lava has flowed over pre-existing scarps and abuts the horst. There is virtually no vegetation on the cone or flow.
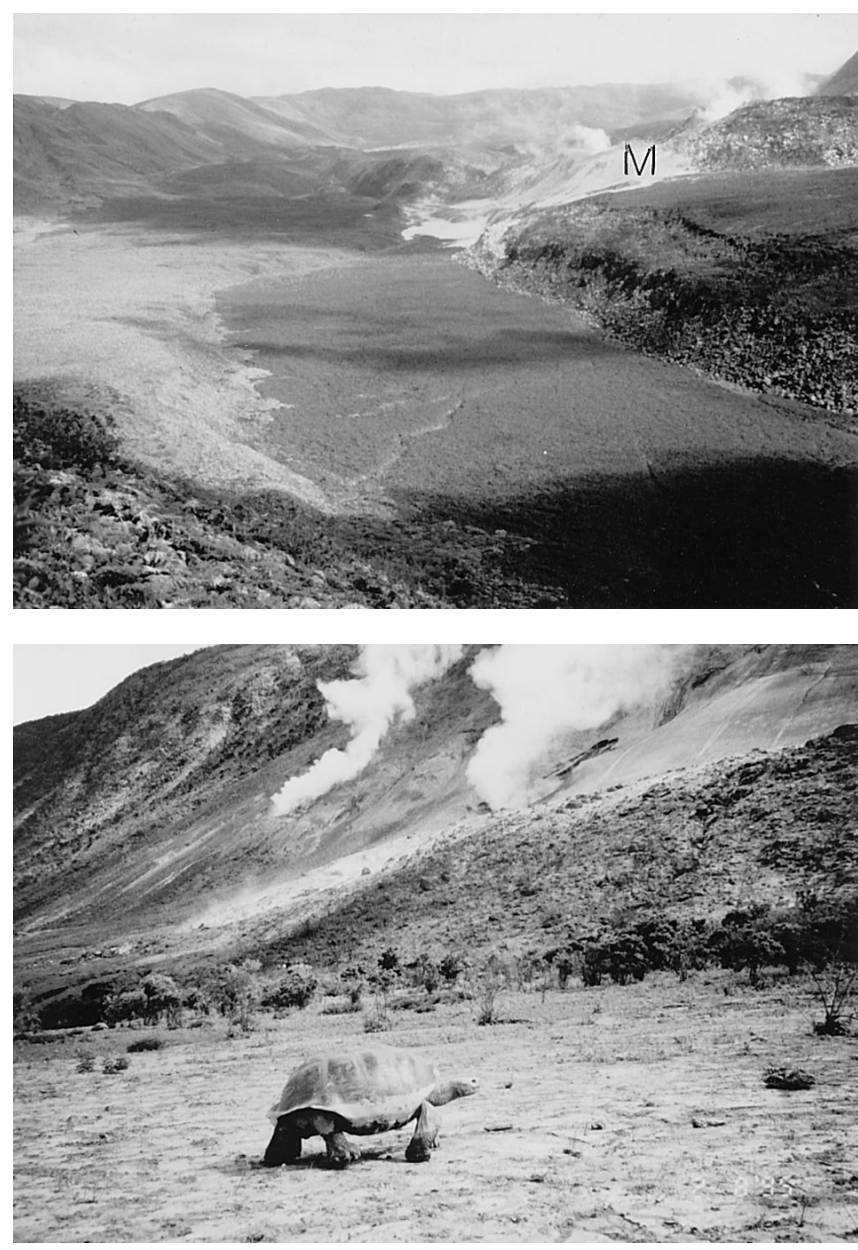

Fig. 2 a Mina Azufral $(M)$ looking north from SW caldera rim, Sierra Negra. Fumarole clusters have formed on steeply dipping normal faults on the west side of an intracaldera horst that tilts gently to the east. The faulted boundaries of this horst form the "sinuous ridge" so widely cited in the Sierra Negra literature. Age-4 flows (Reynolds et al. 1995) partially fill the western moat, post-dating most uplift of the horst. The maximum elevation of the horst is equivalent to the elevation of the western caldera wall. Growth of an intracaldera horst of this size is unusual for basaltic shield volcanoes and is analogous in appearance to structural resurgent domes characteristic of many silicic calderas (Smith and Bailey 1968) b Laura and Chantel fumaroles, viewed tose from the Alcedo caldera floor. Total discharge rate of both fumaroles was estimated at approximately $15 \mathrm{~m}^{3} / \mathrm{s}$. The fumaroles formed in 1993-1994 and issue from hydrothermal explosion craters that have an apron of small rock fragments covered with light gray mud and silt. The explosion deposits contain trace metal anomalies (Table 7) suggesting that low-temperature epithermal fluids are circulating or have circulated at modest depths $(\leq 100 \mathrm{~m})$ below the present land surface. Galapagos tortoise is $0.8 \mathrm{~m}$ high for scale

\section{Alcedo volcano}

Alcedo volcano presents an entirely different geologic aspect compared with Sierra Negra. Firstly, there is no imposing intracaldera horst in Alcedo caldera. The caldera floor is broad, cut by occasional faults of minor throw $(\leq 15 \mathrm{~m})$, and covered either with thick 
vegetation or relatively barren aa lavas. Fumarolic activity is distributed along a 4-km-long stretch of an E-W to WNW-trending fault zone that forms a narrow bench along the lower slope of the southern caldera wall. Fumarolic activity broadens in the southwestern caldera to include an intracaldera rhyolite crater with associated lavas and flow breccias (McBirney et al. 1985). The rhyolite crater is the source of the distinctive rhyolitic pumice-fall deposit that blankets a sector of the northwestern flank of the caldera and extends to the coast (Geist et al. 1994).

Superficially, the fumaroles resemble those at Mina Azufral. However, Alcedo fumarole discharges contain much more water (and thus are whiter in appearance), smell more strongly of $\mathrm{H}_{2} \mathrm{~S}$, and discharge at or slightly below normal boiling temperatures for their altitude $\left(\leq 98^{\circ} \mathrm{C}\right)$. In addition, the fumarole condensates are less acidic $(\mathrm{pH} \geq 3)$, and the altered rocks contain considerably more Fe-oxides and less native sulfur. Sulfur and other acid incrustations are common near active fumaroles but are less abundant than at Mina Azufral fumaroles in Sierra Negra.

Some Alcedo fumaroles are spectacular because they are large, noisy, and issue from hydrothermal explosion craters (Fig. 2b). Alcedo "Geyser" is the easternmost large fumarole and, although not a true geyser, once erupted water periodically (Nordlie and Colony 1973). The fumarole now issues from a rocky hole approximately $5 \mathrm{~m}$ in diameter at the southern edge of an explosion crater approximately $75 \mathrm{~m}$ in diameter. Smaller fumaroles issue from the western and southern walls of this crater. Alcedo geyser crater cuts the west margin of a previous explosion crater that has extremely weak fumarolic activity within it.

Directly west of Alcedo geyser crater is a relatively flat area covered with recently killed trees and shrubs. Weak fumarolic emissions vent from holes and cracks in the ground and from decayed tree stumps. Another $200 \mathrm{~m}$ west of the tree kill is a very deep $(>30 \mathrm{~m})$, steep-walled explosion crater with no present fumarolic activity. This crater has no point of easy access and has a very prominent tortoise skeleton at the bottom, presumably because the animal fell to its death. "Tortoise" crater is also noteworthy because a highangle normal fault is exposed in the east crater wall. Another explosion crater with no apparent fumarolic emissions occurs higher on the caldera wall, southwest of Tortoise crater.

Approximately $1.5 \mathrm{~km}$ west of Tortoise crater, two large fumaroles discharge from very young explosion craters on the south caldera wall approximately 60-80 $\mathrm{m}$ above the caldera floor (Fig. 2b). According to Green (1994), these fumaroles and craters formed in late 1993 to early 1994. The larger one (herein named Chantel) occurs approximately $160 \mathrm{~m}$ west and $20 \mathrm{~m}$ lower on the slope than the smaller one (herein named Laura). Soft deposits of layered gray mud, silt, and small rock fragments form an apron around the explosion craters, most noticeably around Chantel crater which is approximately $75 \mathrm{~m}$ in diameter and $15 \mathrm{~m}$ deep. The walls of Chantel crater have partially collapsed. Chantel fumarole issues from the fractured northwest wall of the crater and much vegetation recently killed by mud and silt deposits lies northwest of the vent. Laura crater is approximately $25 \mathrm{~m}$ in diameter and Laura fumarole issues from a rocky, 5-m-diameter hole inside the crater. Much smaller fumaroles issue from the steep ravine in the caldera wall east of Laura, from the mound of altered landslide debris below (north) of Chantel, and from widely distributed vents all around this area. Another large explosion crater, now mostly devoid of fumarolic activity, sits in the lower caldera wall just west of Chantel crater.

The noise from Chantel and Laura fumaroles is so loud that it is heard on the opposite margin of the caldera when wind conditions are correct. These highpressure fumaroles are probably superheated because steam only begins to condense 1-2 $\mathrm{m}$ above their vents. The total discharge rate of these fumaroles was estimated visually at $15 \mathrm{~m}^{3} / \mathrm{s}$, with Chantel approximately twice the volume of Laura. We could not safely sample either fumarole during our field activities, but could sample smaller vents a few tens of meters away.

Another kilometer west of Chantel fumarole there is a small hill of intermingled basalt and rhyolite (herein named $\mathrm{B} / \mathrm{R}$ hill) containing several low-pressure fumaroles at the summit. From the vantage point of this hill, the fault zone controlling so much of Alcedo's fumarolic activity consists of at least two parallel fault strands that trend WNW, rising obliquely up the west caldera wall. Low-pressure fumaroles and highly altered ground occur along these faults. One kilometer north of $\mathrm{B} / \mathrm{R}$ hill, across a broad flat area with sparse vegetation, rises another hill which consists mostly of rhyolite flows, flow breccias, and tephras. Near the approximate summit of this hill is a crater approximately $0.5 \mathrm{~km}$ in diameter that opens to the east. This is the postulated source of the tephra blanket northwest of Alcedo caldera (Geist et al. 1994). A thick, relatively unaltered flow of rhyolite occurs east of the crater. Low-pressure fumaroles issue from the western rim, walls, and floor of the crater, which are pervasively altered.

At approximately 11:30 a.m. on 7 February 1995, while preparing to sample near Laura fumarole, we heard a muffled explosion and simultaneously felt a small earthquake. Initially, we thought these were manifestations from Fernandina volcano which was erupting approximately $60 \mathrm{~km}$ to the northwest. On further reflection, we now believe that the earthquake and explosion were caused by a subterranean event which occurred within the Alcedo hydrothermal system. Similar phenomena were heard and felt near Alcedo geyser in 1970 (Geist et al. 1994).

It is our opinion that hydrothermal intensity is slowly propagating eastward because the eastern area 
has larger fumaroles, the youngest explosion craters, the least developed alteration, and the most obvious heat-induced vegetation kills. Fumarolic activity in the eastern zone is controlled exclusively by faults. In contrast, activity in the west is broadly distributed and the alteration is more pervasive. Explosion craters are partially to completely revegetated and more subdued. Activity appears to be controlled by a combination of caldera-margin faults and by nearby rhyolite vents that undoubtedly created subsurface fracture networks and intrusion breccias during magma emplacement.

\section{Sampling and analytical methods}

Gas and water sampling methods are described by Fahlquist and Janik (1992) and Trujillo et al. (1987), respectively; field data are presented in Table 1. Temperatures were obtained with portable digital thermometers connected to thermocouples or with standard thermometers. Field measurements of $\mathrm{pH}$ were obtained with $\mathrm{pH}$-sensitive papers. Flow rates were measured with a bucket/beaker and stop watch or were estimated visually.

Fluid samples were collected from fumaroles using either pure silica tubes, titanium tubes, or (for one

Table 1 Field data for fluid and rock samples collected at Sierra Negra and Alcedo volcanoes, Galapagos Archipelago

\begin{tabular}{|c|c|c|c|c|c|}
\hline \multicolumn{6}{|l|}{ Fluid samples } \\
\hline Sample no. & Description & Date $(\mathrm{m} / \mathrm{d} / \mathrm{y})$ & Temp $\left({ }^{\circ} \mathrm{C}\right)$ & Field $\mathrm{pH}$ & Flow $(1 / \mathrm{min})$ \\
\hline \multicolumn{6}{|l|}{ Sierra Negra volcano } \\
\hline SNV-2 & Seawater at Villamil beach & $1 / 23 / 95$ & 27 & 7 & - \\
\hline SNV-3 & Water supply well (Chapín) & $1 / 23 / 95$ & 25 & 7 & $0-200$ \\
\hline SNV-4 & Pool, small lava tube (Manzanillo) & $1 / 23 / 95$ & 24.5 & 6 & Seep \\
\hline SNV-5 & Spring (El Curo) & $1 / 24 / 95$ & 25 & 6.5 & $2^{-1}$ \\
\hline SNV-6 & Fumarole, lower group (M. Azufral) & $1 / 25 / 95$ & 196 & 1.2 & - \\
\hline SNV-7 & Fumarole, lower group (M. Azufral) & $1 / 25 / 95$ & 155 & 1.5 & - \\
\hline SNV-8 & Rain at Villamil & $1 / 27 / 95$ & 22 & - & - \\
\hline SNV-9 & Spring in estuary (Estero \#2) & $1 / 27 / 95$ & 22.5 & 6 & Seep \\
\hline SNV-10 & Pool, small lava tube (Airport) & $1 / 27 / 95$ & 23.5 & 7 & Seep \\
\hline SNV-11 & Spring (El Boliche) & $1 / 27 / 95$ & 20.7 & 6.5 & Seep \\
\hline SNV-12 & Spring (La Ventana) & $1 / 27 / 95$ & 19.4 & 6 & Seep \\
\hline SNV-13 & Cistern (Escuela La Esperanza) & $1 / 27 / 95$ & 22.3 & 6 & - \\
\hline SNV-15 & Fumarole, lower group (M. Azufral) & $1 / 29 / 95$ & 183 & 1.2 & - \\
\hline SNV-16 & Fumarole, higher group (M. Azufral) & $1 / 30 / 95$ & 208 & 1.2 & - \\
\hline SNV-17 & Fumarole, lower group (M. Azufral) & $1 / 30 / 95$ & 172 & 1 & - \\
\hline SNV-18 & Rain at west rim of caldera & $1 / 30 / 95$ & 21 & - & - \\
\hline SNV-19 & Rain at Villamil & 2/01/95 & 23 & - & - \\
\hline \multicolumn{6}{|l|}{ Alcedo volcano } \\
\hline AV-1 & Fumarole inside Alcedo geyser & 2/04/95 & 96.2 & 4.5 & _ \\
\hline AV-2 & Just below new fumarole (Chantel) & $2 / 05 / 95$ & 97.2 & 4.5 & - \\
\hline AV-3 & Pond, caldera floor by new fumaroles & 2/06/95 & 25 & 6 & - \\
\hline AV-4 & Just south of new fumarole (Laura) & $2 / 07 / 95$ & 95.7 & 3 & - \\
\hline AV-5 & Pond on south flank of volcano & $2 / 07 / 95$ & 25 & 6 & - \\
\hline AV-6 & Fumarole on basalt/rhyolite hill & $2 / 08 / 95$ & 96.1 & 4.5 & - \\
\hline AV-8 & Fumarole, $\mathrm{W}$ rim of rhyolite crater & $2 / 09 / 95$ & 97.0 & 4.0 & - \\
\hline AV-9 & Fumarole, $\mathrm{W}$ rim of rhyolite crater & 2/09/95 & 97.0 & - & - \\
\hline AV-10 & Fumarole, floor of rhyolite crater & 2/09/95 & 97.4 & - & - \\
\hline AV-11 & Rain, SE rim of caldera & 2/10/95 & 25 & - & - \\
\hline \multicolumn{6}{|l|}{ Rock samples } \\
\hline Sample no. & \multicolumn{5}{|l|}{ Description } \\
\hline \multicolumn{5}{|l|}{ Sierra Negra volcano } & Mixture of sublimates from $196^{\circ} \mathrm{C}$ fumarole, Mina Azufral \\
\hline jaSNV-1a & \multicolumn{5}{|c|}{ Pinkish sulfur chunks from sample jaSNV-1, Mina Azufral } \\
\hline jaSNV-3 & \multicolumn{5}{|c|}{ Sulfur from crack ca. $3 \mathrm{~m}$ from SNV-6, Mina Azufral } \\
\hline jaSNV-4 & \multicolumn{5}{|c|}{ Sulfur from crack ca. $1 \mathrm{~m}$ from SNV-6, Mina Azufral } \\
\hline jaSNV-5 & \multicolumn{5}{|c|}{ Mixture of yellow and orange sulfur from vent ca. $4 \mathrm{~m}$ from SNV-6, Mina Azufral } \\
\hline Alcedo volcano & \multirow{2}{*}{\multicolumn{5}{|c|}{ Phreatic explosion tephra from crater rim of largest new fumarole (Chantel) }} \\
\hline jaAL-3B & & & & & \\
\hline jaAL-3C & \multicolumn{5}{|c|}{ Phreatic explosion tephra $10 \mathrm{~m}$ downslope of jaAL-3B } \\
\hline jaAL-4 & \multicolumn{5}{|c|}{ Sulfur from fumarole in basalt/rhyolite hill (gas sample AV-6) } \\
\hline jaAL-7 & \multicolumn{5}{|c|}{ Phreatic explosion tephra from crater rim of Alcedo geyser } \\
\hline jaAL-9 & \multicolumn{5}{|c|}{ Sulfur from fumarole at west rim of rhyolite crater (gas sample AV-8) } \\
\hline
\end{tabular}


deep fumarole pit at Mina Azufral) a combination of both tubes in series. The tubes were buried in the throats of the fumaroles and backfilled with earth to prevent air contamination. Various adapters and silicone tubing connected the tubes to condensers and sampling containers. Gases were collected into evacuated 300-ml double-port flasks filled with approximately $100 \mathrm{ml}$ of 4-N high-purity, low-carbonate $\mathrm{NaOH}$. Condensates were obtained in customized silica glass condensers and stored in polypropylene bottles. Because no ready source of ice is available in these remote locations, cool water was packed in as the condensing agent. Noble gas samples were collected into special leaded glass vials equipped with vacuum stopcocks or into copper tubes sealed with a crimping tool, depending on $\mathrm{pH}$ of the fluid. (Copper was used for more neutral $\mathrm{pH}$ conditions.)

At each water sampling site $125-\mathrm{ml}$ aliquots of filtered water $(0.45 \mu \mathrm{l})$ were collected in polypropylene bottles for chemistry, 30-ml aliquots of raw sample (i.e., unfiltered and untreated) were collected in glass bottles for stable isotope analysis, and 500-ml aliquots of raw water were collected in polypropylene bottles for tritium analysis. If necessary, $\mathrm{HNO}_{3}$ was added to one of the $125-\mathrm{ml}$ aliquots to bring the $\mathrm{pH}$ to $<2$. Samples of rocks, fumarole sublimates, and explosion tephras were collected with hammers or scoops and placed in plastic or cloth bags for later laboratory work.

Chemical analyses of gases and waters were performed at Los Alamos National Laboratory (LANL) following procedures described by Fahlquist and Janik (1992) and Trujillo et al. (1987). Head-space gases were analyzed with a double-gas chromatograph (GC) system configured in parallel using helium and argon carriers. Dissolved acid gases and water vapor were analyzed in the caustic solutions by titration and gravimetric methods. After analysis of the caustic solutions, splits were sent to Geochron Laboratories (Cambridge, Mass.) for determination of carbon-13 and sulfur-34 contents of dissolved $\mathrm{CO}_{2}$ and total $\mathrm{S}$ species, respectively. Noble gases were analyzed at Vrije Universiteit (Amsterdam) using extraction and mass spectrometer techniques described by Van Soest et al. (1998). Only $\mathrm{He}$ data and $\mathrm{He} / \mathrm{Ne}$ ratios are reported here because the noble gas results will be the subject of another paper.

Waters were analyzed at LANL by a combination of inductively coupled plasma, graphite furnace atomic absorption, anion chromatography, specific ion electrode, hydride generator, and $\mathrm{pH}$ titration methods. Stable isotope and tritium samples were analyzed at Southern Methodist University (Dallas, Texas) and University of Miami (Florida), respectively, using standard procedures (e.g., Dugan et al. 1985; Ostlund et al. 1974).

Hydrothermal sulfur and explosion tephra were analyzed for their metal contents by wet chemical methods at LANL. Selected samples were also analyzed by Bonder-Clegg (Reno, Nevada). Mineral identification of incrustations was made by X-ray diffraction methods. Analytical results for all types of samples are listed in Tables 2, 3, 4, 5, 6, and 7 .

\section{Geochemistry}

Isotopes of background waters and fumarole condensates, Sierra Negra

The majority of background samples (Table 2) were obtained from the southeast flank of Sierra Negra volcano for two reasons. Firstly, this area is a relatively wet zone on Isabela Island where warm, moist air rising off the ocean condenses to form clouds at the flank and summit of the volcano. Secondly, because it is wetter, this zone supports the only permanent human population on the island and the local residents know where the springs and pools occur.

Isotopic compositions of most Sierra Negra meteoric waters range between 0 and $-10 \% \delta \mathrm{D}$ and plot parallel the World Meteoric Line (WML) of Craig (1961). Two rain samples have much more depleted values, as low as $-24 \%$. As expected, samples at higher elevation generally have more depleted isotope values. A sample of seawater from Villamil beach has a composition nearly identical to standard mean ocean water (SMOW).

Fumaroles at Mina Azufral produce steam that consistently yields isotope values that plot to the left of the WML. This is also a characteristic of many fumaroles at Kilauea, Hawaii (Hinkley et al. 1995; Goff and McMurtry, in press). Most of the steam samples, including the one from the hottest sampled fumarole $\left(208^{\circ} \mathrm{C}\right)$, have deuterium values very similar to most local meteoric waters. To calculate hypothetical parent compositions of the water that boiled to produce the resulting steam, we use fractionation factors presented by Henley et al. (1984). If we assume that this steam has been created during boiling of water at measured sampling temperatures, the parent compositions for this group of condensate samples form a cloud that overlaps the range of most local meteoric waters, although the overlap is far from perfect (Fig. 3).

The largest and hottest fumarole in the lower fumarole group $\left(196^{\circ} \mathrm{C}\right)$ issues from a pit approximately $4 \mathrm{~m}$ in diameter and approximately $2 \mathrm{~m}$ deep. Steam discharged from this fumarole displays an isotopic composition much more depleted than other steam condensates, even though it is located only tens of meters from some of the other sampling sites. When the parent water composition is calculated for this steam (at discharge temperature), the parent fluid appears to be meteoric water resembling the high-altitude rain sample collected from the caldera rim.

The depleted $\delta^{18} \mathrm{O}$ values of the steam could be explained in part by fractionation between $\mathrm{H}_{2} \mathrm{O}$ and 
Table 2 Stable isotope and tritium data for fluids at Sierra Negra and Alcedo volcanoes

\begin{tabular}{|c|c|c|c|c|c|}
\hline Sample no. & Description & Temp $\left({ }^{\circ} \mathrm{C}\right)$ & $\delta \mathrm{D}(\%)$ & $\delta^{18} \mathrm{O}(\%)$ & ${ }^{3} \mathrm{H}$ (T.U.) \\
\hline \multicolumn{6}{|c|}{ Sierra Negra volcano } \\
\hline SNV-2 & Seawater & 27 & $-1.35(2)$ & $-0.07(2)$ & $1.40 \pm 0.16$ \\
\hline SNV-3 & Well & 25 & -9.1 & -3.05 & $0.42 \pm 0.11$ \\
\hline SNV-4 & Pool & 24.5 & -4.8 & -1.93 & $1.22 \pm 0.10$ \\
\hline SNV-5 & Spring & 25 & +0.3 & -1.68 & $1.43 \pm 0.09$ \\
\hline SNV-6a & Fumarole & 196 & -31.4 & -6.79 & $0.35 \pm 0.09$ \\
\hline SNV-6b & Fumarole & 196 & $-37.0(2)$ & $-8.09(2)$ & - \\
\hline SNV-7 & Fumarole & 155 & -13.1 & -7.03 & $0.12 \pm 0.12$ \\
\hline SNV-8 & Rain & 22 & -4.8 & -1.58 & $1.52 \pm 0.10$ \\
\hline SNV-9 & Spring & 22.5 & -8.9 & -2.61 & $0.58 \pm 0.10$ \\
\hline SNV-10 & Pool & 23.5 & -5.9 & -2.30 & $1.75 \pm 0.13$ \\
\hline SNV-11 & Spring & 20.7 & $-2.00(2)$ & $-2.22(2)$ & $1.60 \pm 0.12$ \\
\hline SNV-12 & Spring & 19.4 & -2.8 & -1.72 & $2.11 \pm 0.11$ \\
\hline SNV-13 & Cistern & 22.3 & -1.7 & -1.48 & $1.43 \pm 0.09$ \\
\hline SNV-15a & Fumarole & 183 & -8.7 & $-5.26(2)$ & $0.34 \pm 0.09$ \\
\hline SNV-15b & Fumarole & 183 & $-8.0(2)$ & -5.34 & - \\
\hline SNV-16 & Fumarole & 208 & $-8.4(2)$ & $-3.69(2)$ & $0.48 \pm 0.09$ \\
\hline SNV-17a & Fumarole & 172 & -4.0 & -5.30 & $0.25 \pm 0.09$ \\
\hline SNV-17b & Fumarole & 172 & $-3.4(2)$ & -5.40 & - \\
\hline SNV-18 & Rain & 21 & -24.0 & -4.75 & $1.30 \pm 0.09$ \\
\hline SNV-19 & Rain & 23 & -18.1 & -3.38 & $1.65 \pm 0.11$ \\
\hline \multicolumn{6}{|c|}{ Alcedo volcano } \\
\hline AV-1 & Fumarole & 96.2 & $-7.30(2)$ & $-0.28(2)$ & $15.4 \pm 0.5^{\mathrm{a}}$ \\
\hline AV -2 & Fumarole & 97.2 & -17.4 & -2.67 & $0.30 \pm 0.09$ \\
\hline AV-3 & Pond & 25 & -9.7 & -1.19 & $1.54 \pm 0.10$ \\
\hline $\mathrm{AV}-4$ & Fumarole & 95.7 & -22.0 & -2.59 & - \\
\hline AV -5 & Pond & 25 & - & - & $1.41 \pm 0.12$ \\
\hline AV-6 & Fumarole & 96.1 & -26.1 & -3.01 & $1.52 \pm 0.09$ (2) \\
\hline AL-8 & Fumarole & 97.0 & $-5.55(2)$ & $+0.64(2)$ & $0.97 \pm 0.09$ \\
\hline AV -9 & Fumarole & 97.0 & - & - & - \\
\hline AV-10 & Fumarole & 97.4 & -28.8 & -2.22 & - \\
\hline AV-11 & Rain & 25 & -1.1 & -2.15 & $1.18 \pm 0.09$ \\
\hline
\end{tabular}

Stable isotope data is reported relative to SMOW and was analyzed at Texas A\&M University; uncertainties are \pm 1 for $\delta \mathrm{D}$ and \pm 0.15 for $\delta^{18} \mathrm{O}$. Tritium analyzed at University of Miami

Numbers in parentheses mean that two analyses were averaged

${ }^{a}$ Value checked by direct counting
Fig. 3a,b Plots of $\delta \mathrm{D}$ vs $\delta^{18} \mathrm{O}$ and ${ }^{3} \mathrm{H}$ vs $\delta^{18} \mathrm{O}$ for fluids from Sierra Negra volcano $(S N V)$. a Most fumarole condensates plot to left of world meteoric line $(W M L)$ indicating that they evolve by boiling of local meteoric water at temperatures approximating collection temperatures. A line showing $100{ }^{\circ} \mathrm{C}$ boiling of typical local meteoric water is plotted for comparison. Vectors

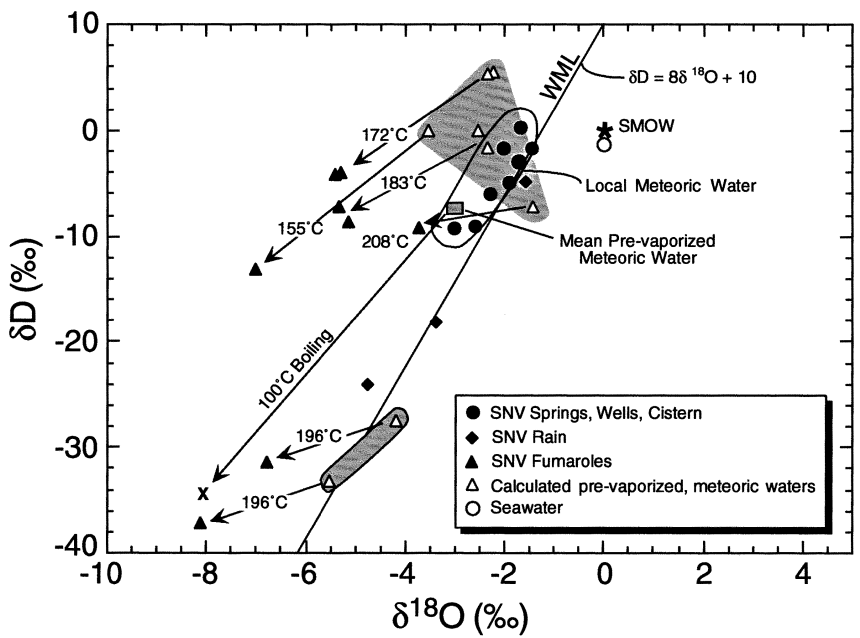

show steam resulting from boiling of hypothetical parents at measured discharge temperatures. b Fumarole samples show increasing tritium with discharge temperature suggesting that fluids from the hotter fumaroles are mixing with younger meteoric waters. 1 T.U. (tritium unit) means 1 tritium per $10^{18}$ hydrogen atoms. SMOW standard mean ocean water

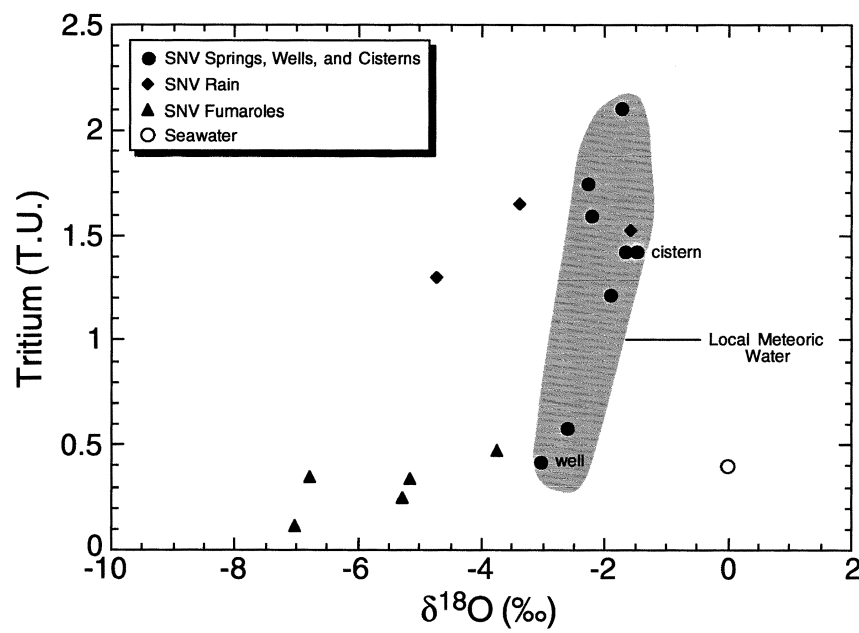


$\mathrm{CO}_{2}$ (Vuataz and Goff 1986) or, in unusual circumstances, between $\mathrm{H}_{2} \mathrm{O}$ and rock (Lowenstern et al. 1999); however, these fractionation processes do not explain the $\delta \mathrm{D}$ variations in Sierra Negra steam, which mimic those observed in local meteoric waters.

The Mina Azufral fumaroles do not contain any isotopically discernible component of magmatic water. "Magmatic waters" as defined herein have $\delta \mathrm{D}$ isotope values of +10 to $-50 \%$, $\delta^{18} \mathrm{O}$ isotope values of +5 to + $10 \%$, and tritium $\left({ }^{3} \mathrm{H}\right)$ contents of 0.0 T.U. (Goff and McMurtry, in press), and plot far to the right of the WML. Magmatic waters as we define them include "arc" or "andesitic" magmatic waters defined by many authors (i.e., Giggenbach 1992a). As seen in Fig. 3a, fumaroles at Mina Azufral produce steam that is formed primarily by boiling of local meteoric waters, not by degassing of magma.

Tritium values of fluids from Sierra Negra are compared in Fig. 3b. Most local meteoric waters plot in a vertical cloud showing constant $\delta^{18} \mathrm{O}$ but variable ${ }^{3} \mathrm{H}$ due to variable age of the anthropogenic input of (post-bomb) tritium. The majority of local meteoric waters including the three rain samples contain more than 1.0 T.U. ${ }^{3} \mathrm{H}$, but two samples (Villamil water supply well and the spring near the estuary) contain $\leq 0.6$ T.U. and thus are composed of somewhat older water. These two sites contain water older than seawater at Villamil beach, which contains approximately 1.4 T.U. Surface seawater is always contaminated with tritium from anthropogenic processes, whereas deep seawater $(\geq 1 \mathrm{~km}$ depth) is practically tritium free (usually <0.1 T.U.; Ostlund et al. 1974).

Fumaroles at Mina Azufral produce steam ranging from 0.1 to 0.5 T.U. ${ }^{3} \mathrm{H}$. Interestingly, there is a correlation between discharge temperature and ${ }^{3} \mathrm{H}$ content. The hottest fumarole has steam with the most ${ }^{3} \mathrm{H}$, suggesting that it contains the youngest meteoric water component. However, the steam produced by these fumaroles does not contain meteoric water $<1$ year old because the steam has much less ${ }^{3} \mathrm{H}$ than recent rain (1.3-1.65 T.U.). To estimate the minimum mean residence time of recycled meteoric water in the fumaroles, we use the "piston-flow" model most recently described by Shevenell and Goff (1995, see tables therein). For waters collected in 1995, values of $0.1-0.5$ T.U. ${ }^{3} \mathrm{H}$ have modeled ages of approximately 45-70 years.

Isotopes of background waters and fumarole condensates, Alcedo

Dry conditions and lack of people familiar with springs prevented us from sampling flowing background waters for comparative purposes at Alcedo caldera. Two ponds were collected but both were highly evaporated and heavily frequented by tortoises, goats, and burros. Using an evaporation slope $=4$ (Craig et al. 1963), the original $\delta \mathrm{D}$ value of this evap- orated water would be approximately $-18 \%$. A sample of rain collected near the summit was only $-1.1 \%$ in $\delta \mathrm{D}$. Because Alcedo is a mere $60 \mathrm{~km}$ north of Sierra Negra, the range of most local meteoric waters from the latter volcano is assumed for Alcedo volcano.

Alcedo fumarole condensates show a 2-3\% isotopic enrichment in $\delta^{18} \mathrm{O}$ relative to the WML; however, there is no apparent trend to the points. Because we strongly suspect that a high-temperature hydrothermal reservoir underlies the southwest sector of the caldera (based on other evidence described herein), we calculated the approximate range of parent water compositions that would best produce the observed steam compositions and have the same apparent $\delta \mathrm{D}$ value of average local meteoric water ("Alcedo Reservoir Water"; Fig. 4). These calculations indicate that a parent reservoir fluid of approximately +1 to $+3 \%$ in $\delta^{18} \mathrm{O}$, formed by isotopic exchange between meteoric water and reservoir rock, boils at subsurface temperatures of 120 to $>200^{\circ} \mathrm{C}$. Using the tables in Henley et al. (1984), fumaroles that produce steam having $\delta \mathrm{D}$ values equivalent to their parent reservoir fluid originate during boiling at temperatures of $220^{\circ} \mathrm{C}$. Two fumarole areas (Alcedo geyser and those at the western rim of the rhyolite crater) contain steam of this isotopic character. Steam at Chantel fumarole seems to be derived form boiling at approximately $160^{\circ} \mathrm{C}$.

Three Alcedo background waters contain 1.2-1.5 T.U. ${ }^{3} \mathrm{H}$. Three of the Alcedo fumaroles produce steam with a range of $0.3-1.5$ T.U. Only Alcedo geyser vents steam with high ${ }^{3} \mathrm{H}$ content

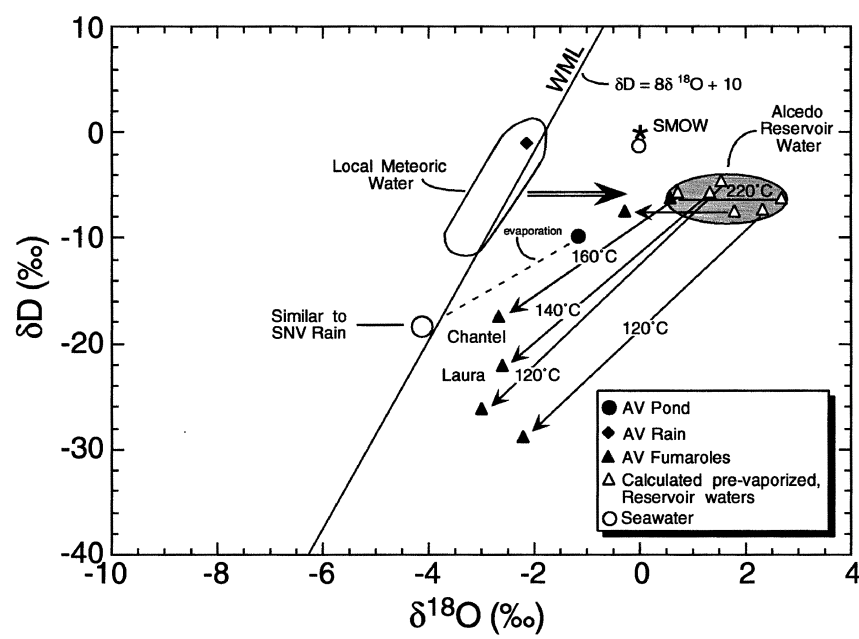

Fig. 4 Plot of $\delta \mathrm{D}$ vs $\delta^{18} \mathrm{O}$ for fluids from Alcedo volcano $(A V)$. Fumarole condensates from Alcedo plot to the right of the world meteoric line $(W M L)$ but do not form any obvious trend. If the condensates are corrected for steam flash (assuming that they are derived from a geothermal reservoir similar in $\delta \mathrm{D}$ to local meteoric water), the corrected points form a cluster approximately $1-3 \%$ o heavier in oxygen-18 that approximates the isotopic composition of the underlying geothermal reservoir. Vectors show steam resulting from boiling of hypothetical parent fluids at plausible temperatures in the top of the reservoir 
(15.4 T.U.), whereas the largest 1993-1994 fumarole (Chantel) vents steam with the least ${ }^{3} \mathrm{H}$. Obviously, the age of some water in the top of the Alcedo reservoir is extremely young, indicating that recharge is relatively rapid. Presumably, relatively young precipitation falling inside the caldera partially recharges the hydrothermal system since we observed no cold springs of any size inside or outside the caldera.

The maximum mean residence time of fluid in the Alcedo reservoir can be estimated using the "wellmixed" model (Goff et al. 1991; Shevenell and Goff 1995). Using a value of 0.3 T.U. ${ }^{3} \mathrm{H}$ for the oldest water, the modeled age for maximum residence time in the Alcedo geothermal reservoir is approximately 400 years. High ${ }^{3} \mathrm{H}$ steam discharged from Alcedo geyser could be as young as 10-30 years even though Alcedo geyser crater is older than the youngest explosion craters (Chantel and Laura).

\section{Gas geochemistry, Sierra Negra}

Fumaroles at Mina Azufral, Sierra Negra, produce gases that are relatively low in water (ca. $75 \mathrm{~mol} . \%$; Table 3). The non-condensable components consist of approximately $97.5 \mathrm{~mol} \% \quad \mathrm{CO}_{2}$. Sulfur gases are mostly $\mathrm{SO}_{2}$; the $\mathrm{H}_{2} \mathrm{~S} / \mathrm{SO}_{2}$ ratio is approximately 0.15 . On a $R_{H}$ vs temperature plot, the Sierra Negra gas samples straddle the $\mathrm{H}_{2} \mathrm{~S} / \mathrm{SO}_{2}$ "gas buffer" (Giggenbach 1996). $\mathrm{HCl}$ is a minor component in the total gas, but quantities among the samples vary by as much as a factor of $12 . \mathrm{HF}, \mathrm{He}, \mathrm{H}_{2}, \mathrm{CH}_{4}$, and $\mathrm{NH}_{3}$ are present but in relatively small amounts. Ratios of $\mathrm{N}_{2} / \mathrm{Ar}$ are similar to air-saturated meteoric water (ASMW). The small variations observable among Mina Azufral samples show mostly differences in relative abundance of water and in $\mathrm{CO}_{2} / \mathrm{S}_{\mathrm{T}}$.

Significant processes influencing Sierra Negra gas compositions are best documented in the $\mathrm{H}_{2} \mathrm{O}$ $\mathrm{CO}_{2}-\mathrm{S}_{\mathrm{T}}$ plot (Fig. 5). Gas compositions from other mafic volcanoes are shown for comparison. The idealized gas composition for White Island andesitic magma (point WI) and a line showing the path of primary vapor degassing of this magma are from Giggenbach (1996). $R_{V}$ is the vapor/melt volume ratio along this path and provides a quantitative measure of degassing. As pointed out by Giggenbach (1996), the composition and degassing path is unique for each magma, but a degassing curve on this plot always defines a crescent-shaped trend between the least soluble gas $\left(\mathrm{CO}_{2}\right)$ and the most soluble gas $\left(\mathrm{S}_{\mathrm{T}}\right)$. Hightemperature gases $\left(\leq 1150^{\circ} \mathrm{C}\right)$ derived from basalt magmas with strong mantle affinities (Kilauea and Erta'Ale volcanoes, points K0 and EA; Fig. 5) contain less water than most andesite magmas, and define degassing paths shifted to the right of the White

Table 3 Gas geochemistry from Mina Azufral, Sierra Negra volcano (values in mol.\% unless noted; CO $<0.00001$ mol.\% in all samples). $P D B$ Pee Dee Belemnite; $C D T$ Canyon Diablo Troilite

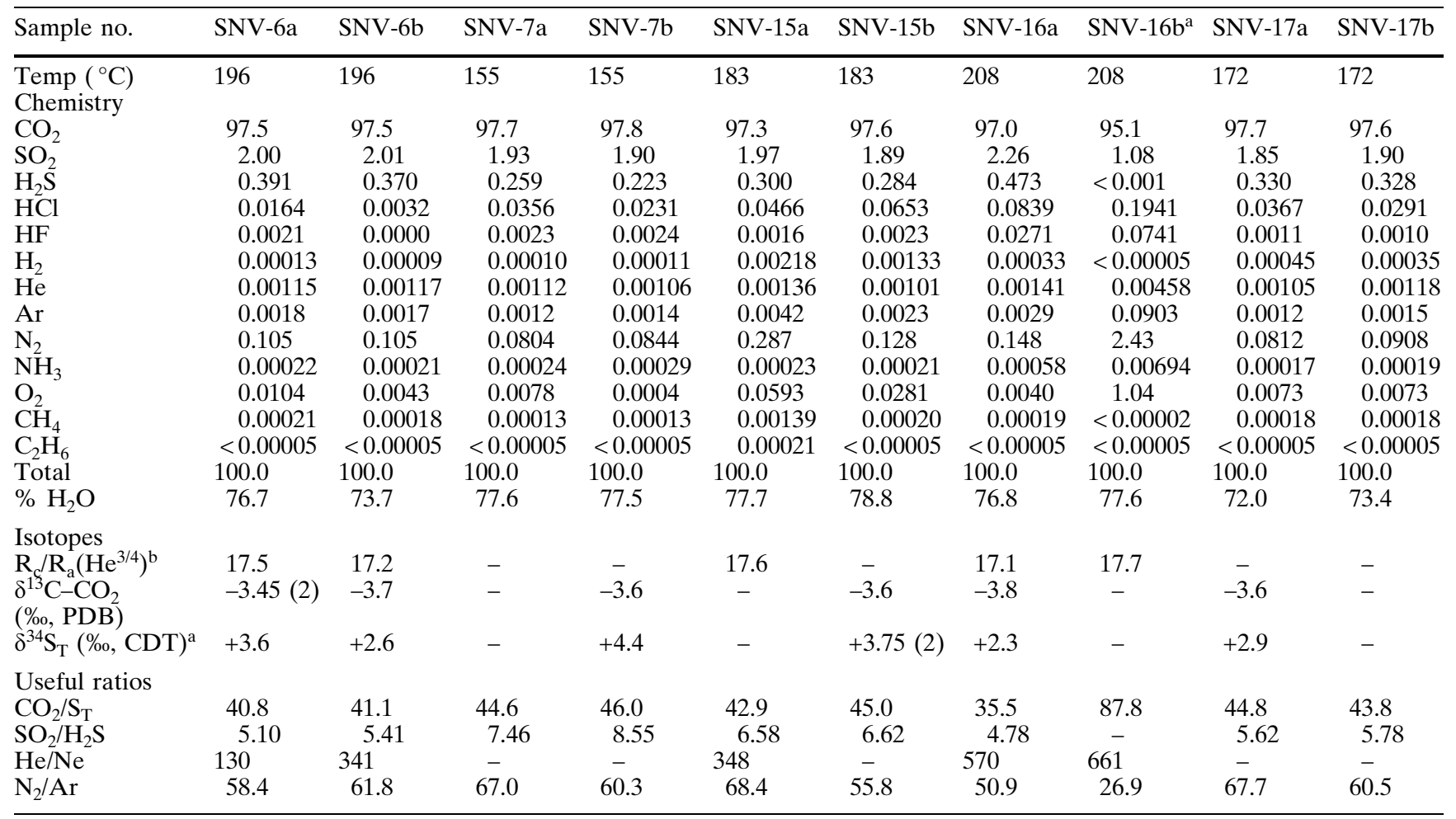

${ }^{a}$ Bulk gas sample contains excess air from sampling problem

${ }^{b}$ Noble gases corrected for air-saturated water dissolved He using He/Ne ratio above and procedures described by Hilton et al. (1998) 


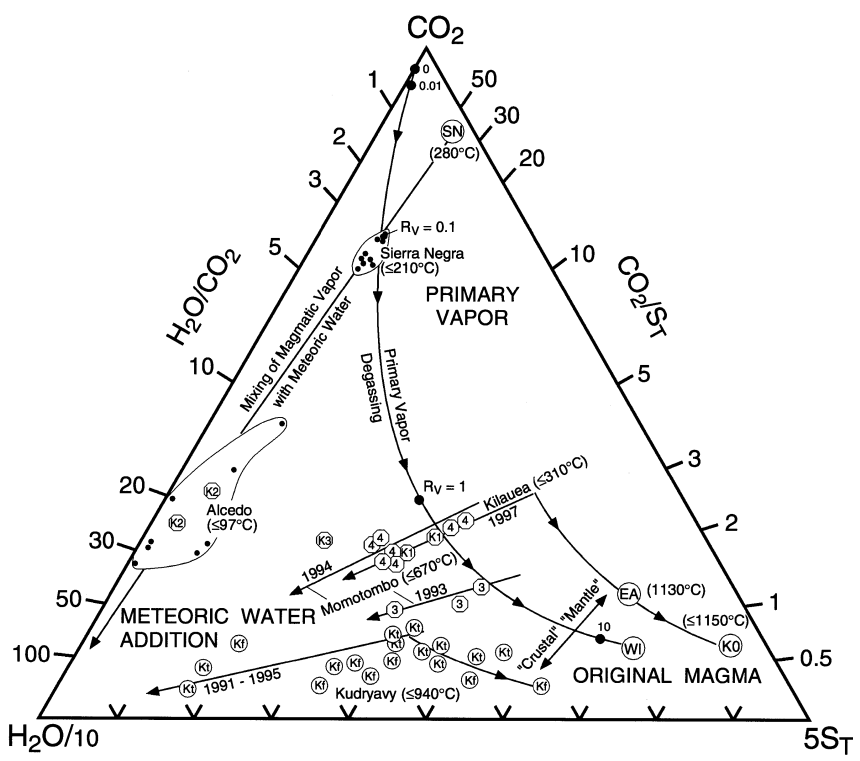

Fig. 5 Triangular plot of $\mathrm{CO}_{2}, \mathrm{~S}_{\mathrm{T}}$ (total sulphur; $\mathrm{SO}_{2}+\mathrm{H}_{2} \mathrm{~S}$ ), $\mathrm{H}_{2} \mathrm{O}$ for gas compositions from Sierra Negra (Mina Azufral), Alcedo, and other sites mentioned in text (values in mol.\%); Sierra Negra gases are relatively $\mathrm{CO}_{2}$ rich, probably originating from degassed primary vapor of basalt magma. Addition of some meteoric water distinguishes our 1995 samples from the previous sample of Giggenbach (1996; point $S N$ ). Alcedo gases appear to be mixtures of a primary vapor and considerably more meteoric water. Mixing with meteoric water is apparently common at other well-characterized basalt volcanoes. Symbols and data: Black dots inside clouds represent our data for Alcedo and Sierra Negra volcanoes; EA, SN, WI Erta'Ale, Sierra Negra, and White Island (Giggenbach 1996); KO Kilauea (Greenland 1984); K1, K2, K3 Kilauea (Goff and McMurtry, in press); $K f$, $K t$ Kudryavy (Fischer et al. 1998 and Taran et al. 1995, respectively); 3, 4 Momotombo 1993 and 1994, respectively (P. LaFemina and D. Counce, unpublished data). (Modified from Giggenbach 1996). $R_{V}$ is the vapor/melt volume ratio

Island trend. On the other hand, gases derived from some basalt magmas within arc settings are richer in water than hot-spot gases due to the addition of water from the subducted slab (Fischer et al. 1998). Depending on the extent of the water addition, such gases may define degassing paths shifted to the left of the White Island trend. An example of the latter is Kudryavy volcano (basaltic andesite, symbols $\mathrm{Kf}$ and $\mathrm{Kt}$ ) from which samples $\leq 940^{\circ} \mathrm{C}$ were collected during 1991-1995 (Taran et al. 1995; Fischer et al. 1998). Samples $\leq 670^{\circ} \mathrm{C}$ collected from Momotombo volcano (high-alumina tholeiite) in 1993 and 1994 (P. LaFemina and D. Counce, unpublished data) are relatively undegassed compared with the Kudryavy example but probably had an initial gas composition similar to that in White Island magma. The 1994 Momotombo samples are systematically less degassed than 1993 samples suggesting that new magma had entered the volcano after the 1993 collection.

A sample of Mina Azufral gas collected at $280{ }^{\circ} \mathrm{C}$ in the early 1990s (point SN; Giggenbach 1996) contains less water than gas samples we collected in 1995 $\left(\leq 210{ }^{\circ} \mathrm{C}\right.$ ). From consideration of the foregoing discussion, the previous, hotter sample (SN) likely followed a degassing path to the right of the ones shown in Fig. 5 and probably represents primary vapor from underlying Sierra Negra magma. The cooler samples can be explained by mixing of this magmatic vapor with some relatively shallow meteoric water along the mixing path shown. As noted above, the 1995 gases contain measurable amounts of tritium. Mixing of magmatic and meteoric fluids is relatively common at basalt volcanoes and is discussed in more detail below.

As magma degasses, the primary vapor becomes enriched in $\mathrm{HCl}$ relative to $\mathrm{S}_{\mathrm{T}}$ and $\mathrm{CO}_{2}$. Ideally, the degassing trend would be represented by curves such as the White Island trend shown in Fig. $6 . \mathrm{HCl}$ can be removed by dissolution into condensing magmatic water, into near-surface meteoric waters, or into mixtures of both. Few (if any) gas analyses plotted in Fig. 6 can be explained only by primary degassing; most show moderate to extreme $\mathrm{HCl}$ removal. Samples from Sierra Negra are no exception.

Relative amounts of $\mathrm{He}, \mathrm{N}_{2}$, and $\mathrm{Ar}$ in Sierra Negra gases are shown in the triangular plot (Fig. 7) and compared with those from many other volcanoes. Sierra Negra gases have a relatively large excess of He characteristic of mantle derived volatiles, but also show an obvious dilution trend with ASMW.

He isotope results for Sierra Negra gases yield air corrected ${ }^{3} \mathrm{He} /{ }^{4} \mathrm{He}$ ratios of $17.4 \pm 0.3 \mathrm{R}_{\mathrm{A}}$ (Fig. 7). It is

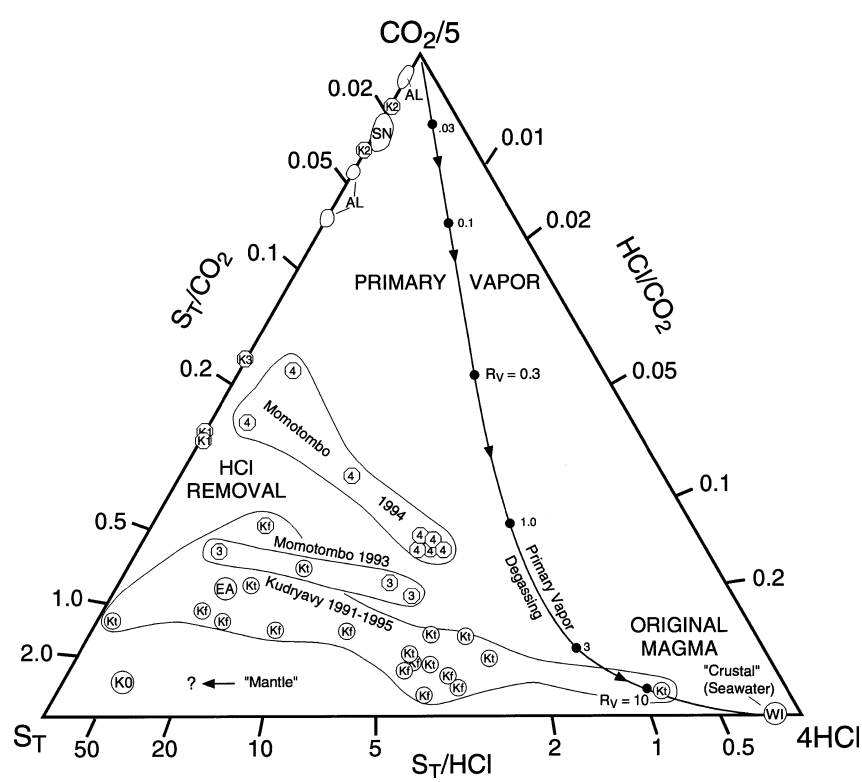

Fig. 6 Triangular plot of $\mathrm{CO}_{2}, \mathrm{~S}_{\mathrm{T}}$, and $\mathrm{HCl}$ for gas compositions from Sierra Negra (Mina Azufral), Alcedo, and other volcanoes (values in mol.\%). Sierra Negra and Alcedo gases are relatively $\mathrm{HCl}$ poor due to probable absorption of $\mathrm{HCl}$ into meteoric waters. Such processes are suggested by data from other basaltic volcanoes. Note that calculated end-member composition for original White Island magma $(W I)$ is identical in composition to seawater. Symbols and data same as in Fig. 5. (Modified from Giggenbach 1996) 


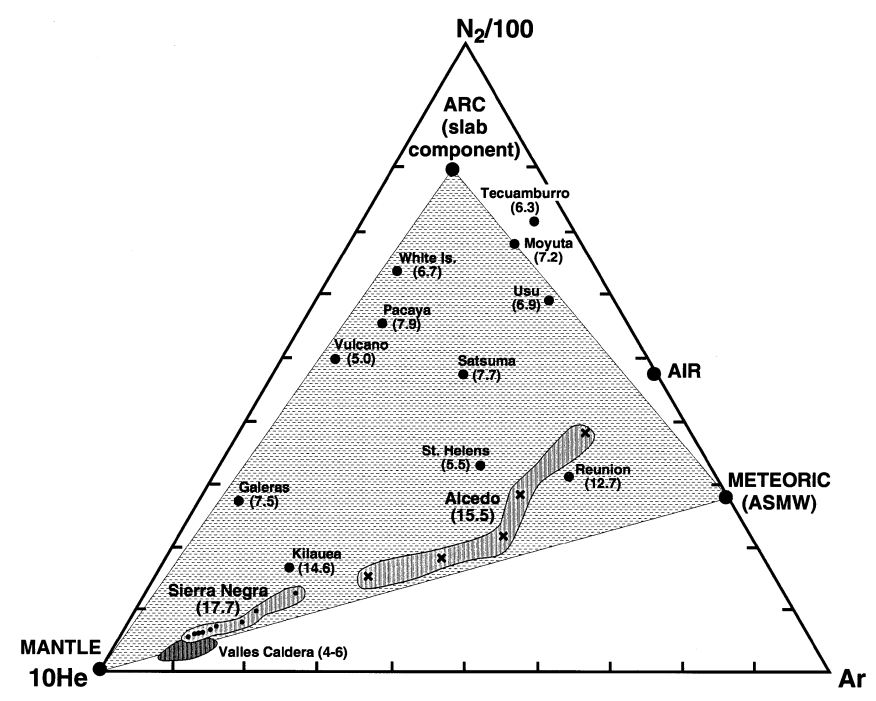

Fig. 7 Triangular plot of $\mathrm{He}, \mathrm{N}_{2}$, Ar for gas compositions from Sierra Negra, and Alcedo volcanoes compared with some other volcanoes and volcanic-hosted geothermal systems (values in mol.\%); values in parentheses give the He-isotope ratios. Mina Azufral gases show a distinct mantle signature but also show dilution with air-saturated meteoric water $(A S M W)$. Alcedo gases show considerably more dilution with ASMW and with air than Sierra Negra gases. Example arc volcanoes are relatively enriched in $\mathrm{N}_{2}$ compared with hot-spot volcanoes, independent of magma composition, because of nitrogen addition from the underlying slab. Interestingly, Valles caldera, which has produced more than $600 \mathrm{~km}^{3}$ of predominately high-silica rhyolite from $1.62 \mathrm{Ma}$ to $60 \mathrm{ka}$, presently discharges hydrothermal gases with obvious mantle affinities. Data sources: Vulcano, Usu, and White Island (Giggenbach and Matsuo 1991); Reunion (Marty et al. 1993); Galeras, Kilauea, Moyuta, Pacaya, Satsuma, St. Helens, and Tecuamburro (Janik et al. 1992; Goff and McMurtry, in press; D.R.Hilton, G.M. McMurtry, and F. Goff, unpublished data); Valles Caldera (Smith and Kennedy 1985; Goff and Gardner 1994). (Modified from Goff and Janik 1993)

no surprise that a hot-spot volcano, such as Sierra Negra, has such high ratios, since magma generation occurs in the deeper mantle. Other hot-spot volcanoes, such as Kilauea, Reunion, and Yellowstone (data not shown), have values of $\geq 13 R_{A}$ (see Farley and Neroda 1998 for a compilation). In contrast, arc volcanoes typically have ${ }^{3} \mathrm{He} /{ }^{4} \mathrm{He}$ ratios $\leq 8 \mathrm{R}_{\mathrm{A}}$ (e.g., Poreda and Craig 1989).

Carbon-13 values of Mina Azufral $\mathrm{CO}_{2}$ average approximately $-3.6 \%$ and are near the enriched side of the range that is used to define a mantle signature ( -3 to $-8 \%$ based on values expected for carbonatites, kimberlites, and diamonds; Rollinson 1993). Values for other hot-spot volcanoes range from -2 to $-7 \%$ (Fig. 8). Most arc volcanoes have carbon isotope compositions that are more depleted in $\delta^{13} \mathrm{C}-\mathrm{CO}_{2}$ than hot-spot volcanoes due to addition of organic carbon from the underlying slab.

The average sulfur-34 value for total sulfur species in Mina Azufral gases is approximately $+3.3 \%$, which is somewhat higher than the accepted range for mantle-derived sulfur $(0 \pm 3 \%$; Rollinson 1993). This sug-

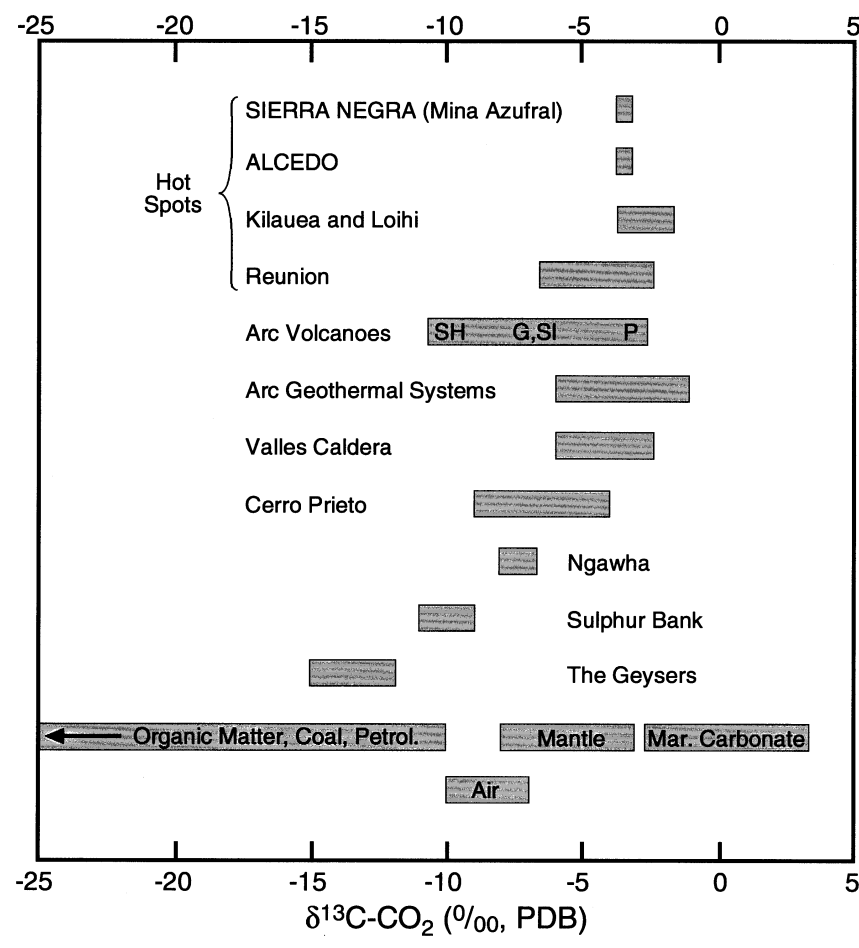

Fig. 8 Diagram comparing carbon isotope ratios of $\mathrm{CO}_{2}$ in Sierra Negra and Alcedo gases to selected volcanoes, geothermal systems, and common carbon sources (Rollison 1993). Sierra Negra and Alcedo gases plot at the depleted range of mantle compositions and isotopically resemble gases from the Hawaiian hot spot (e.g., Hilton et al. 1998), some gases from the Reunion hot spot (Marty et al. 1993), and gases from Pacaya, a high-alumina tholeiite volcano ( $P$; Goff and McMurtry, in press). More silicic volcanoes, such as Galeras ( $G$, andesite), St. Helens ( $S H$, dacite), and Satsuma Iwo-jima (SI, rhyolite) are commonly depleted in $\delta^{13} \mathrm{C}-\mathrm{CO}_{2}$ due to organic carbon contributions from the underlying slab. Geothermal reservoirs hosted in sedimentary rocks such as Ngawha, Sulphur Bank, Cerro Prieto, and The Geysers show influence of isotopically depleted organic carbon (Goff and Janik 1993). Marine limestone can contribute isotopically heavy carbon during decarbonation reactions; thus, isotopes of $\mathrm{CO}_{2}$ from Valles caldera may be influenced by decarbonation of marine limestone beneath the reservoir (Goff and Gardner 1994). Additional data sources same as in Fig. 7 except Arc Geothermal Systems, Sulphur Bank, and The Geysers (Goff and Janik 1993); Cerro Prieto (Janik et al. 1982); Ngawha (Giggenbach and Lyon 1977). PDB is Pee Dee Belemnite, ${ }^{13} \mathrm{C}$ reference standard

gests that the isotopically enriched $\mathrm{S}_{\mathrm{T}}$ results from $\mathrm{SO}_{2}$ outgassed by a shallow mafic melt in which the dominant $\mathrm{S}$ species is sulfide (Sakai et al. 1982).

Gas geochemistry, Alcedo

Unlike gases at Sierra Negra, Alcedo gases resemble those from high-temperature geothermal systems because of their high water content (as much as 97 mol.\%) and predominance of reduced sulfur (Table 4). From examination of Fig. 5, it appears that Alcedo gases are formed by mixing Alcedo magmatic 
Table 4 Gas geochemistry of Alcedo volcano (values in mol.\% unless noted). Number of analyses in parentheses

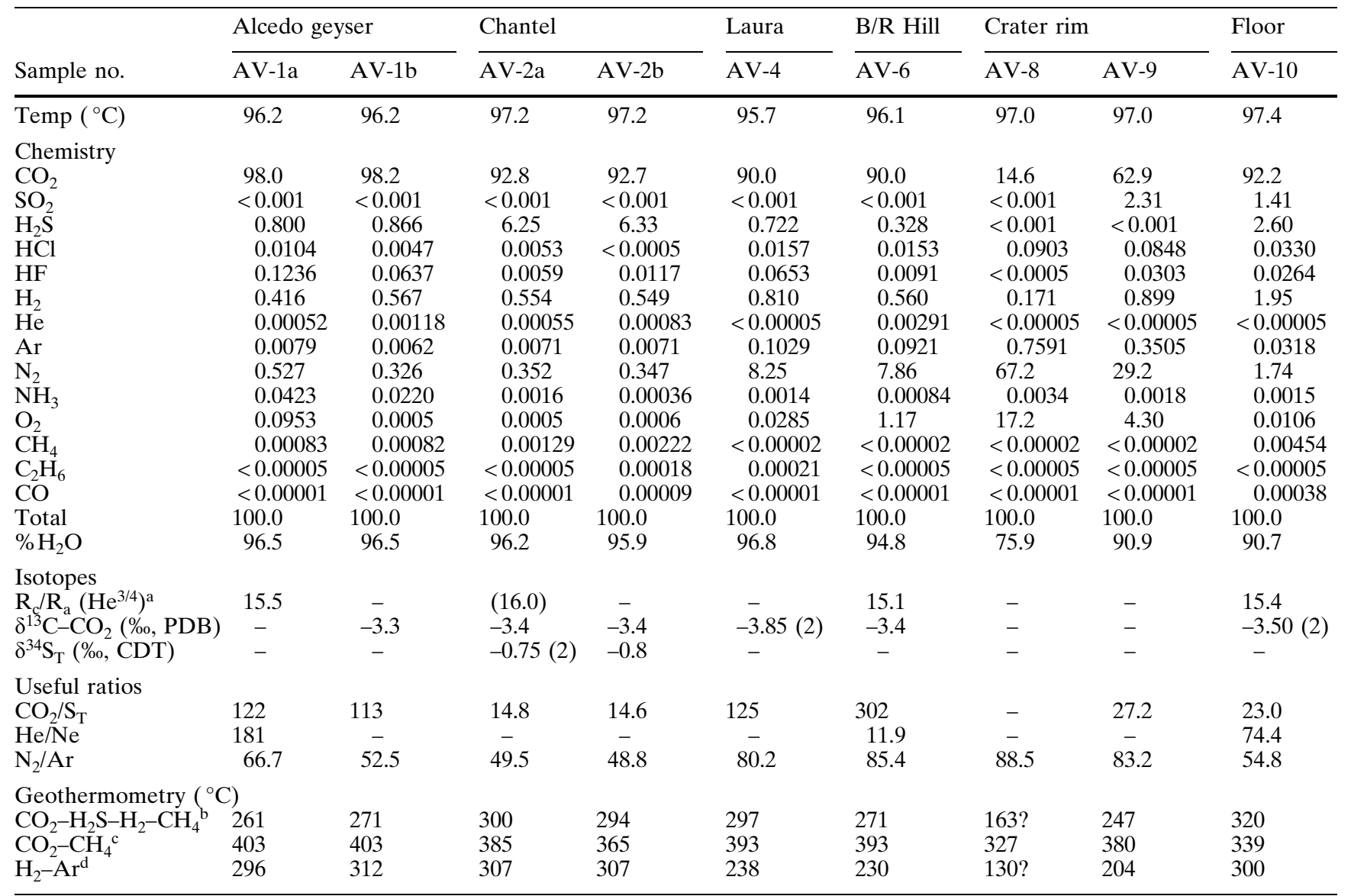

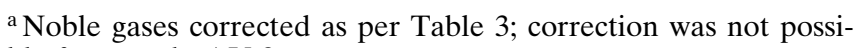
ble for sample AV-2a

${ }^{b}$ From D'Amore and Panichi 1980; all S assumed to be $\mathrm{H}_{2} \mathrm{~S}$; ${ }^{\mathrm{d}}$ From Giggenbach (1992b)

assumes $0.00001 \mathrm{~mol} \% \mathrm{H}_{2}$ if none detected

vapor with copious amounts of meteoric water. As noted previously, Alcedo gases contain significant amounts of tritium. Coincidentally, Alcedo and Sierra Negra gases fall on the same mixing trend. Variable $\mathrm{SO}_{2}$ was detected in Alcedo gases. No $\mathrm{SO}_{2}$ was detected in fumaroles along the southwestern caldera margin fault, but significant $\mathrm{SO}_{2}$ was found in two samples near the rhyolitic crater. The latter samples may contain enhanced $\mathrm{SO}_{2}$ from oxidation of sulfur compounds by air contamination, either in the vent or in the bottle. Alcedo gases contain very little $\mathrm{HCl}$, probably because the original magmatic $\mathrm{HCl}$ is dissolved in geothermal reservoir water (Fig. 6). On the other hand, Alcedo gases contain slightly more $\mathrm{HF}$ and $\mathrm{NH}_{3}$, and significantly more $\mathrm{H}_{2}$, than Mina Azufral gases.

Alcedo gases can be compared to those from other geothermal systems in the $\mathrm{CO}_{2}-\mathrm{H}_{2} \mathrm{~S}-\mathrm{CH}_{4}$ plot of Fig. 9 (modified from Goff and Janik 1993). Alcedo gases are extremely depleted in $\mathrm{CH}_{4}$ compared with geothermal gases hosted in sedimentary rocks (i.e., The Geysers and Ngawha) because there are no underlying organic-rich source rocks. Alcedo gases are similar to gases from other geothermal reservoirs hosted in volcanic rocks. The primary variation observed in Alcedo gases is in relative proportions of $\mathrm{CO}_{2} / \mathrm{S}_{\mathrm{T}}$. Fumaroles closer to the rhyolite crater are richer in $\mathrm{SO}_{2}$ than those further east along the fault zone, such as Alcedo geyser. When the Alcedo gases are plotted on a $R_{H}$ vs temperature diagram, they fall just below the $\mathrm{FeO} /$ $\mathrm{Fe}_{2} \mathrm{O}_{3}$ "rock buffer" line (Giggenbach 1996). Lowpressure fumaroles at $\mathrm{B} / \mathrm{R}$ hill and the rhyolite crater rim contain large amounts of air. When subsurface reservoir temperatures are calculated from the gas compositions using empirical geothermometers (Table 4; $\mathrm{S}_{\mathrm{T}}$ converted to $\mathrm{H}_{2} \mathrm{~S}$ ), Alcedo gases appear to have equilibrated at temperatures $\geq 260^{\circ} \mathrm{C}$.

The deep mantle signature in Alcedo gases is less pronounced than in Mina Azufral gases (Fig. 7). The ${ }^{3} \mathrm{He} /{ }^{4} \mathrm{He}$ ratio is $15.5 \pm 0.4 \mathrm{R}_{\mathrm{A}}$ at Alcedo and the gases show considerably more interaction with air and ASMW. Carbon-13 values of $\mathrm{CO}_{2}$ average $-3.5 \%$ (Fig. 8) and sulfur-34 values of total sulfur are approximately $-0.8 \%$, both within the ranges accepted for 


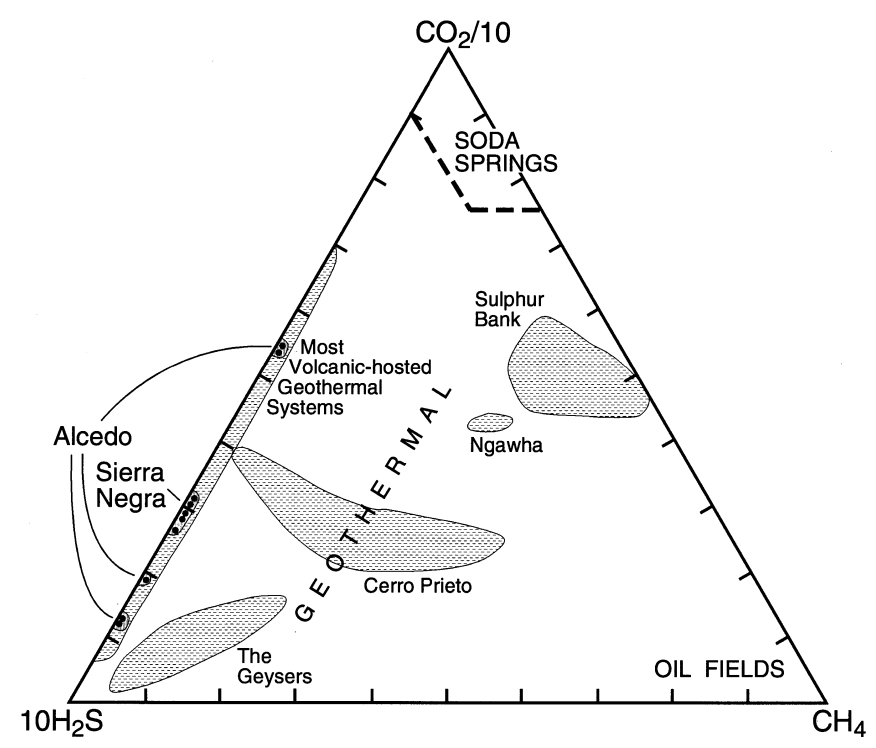

Fig. 9 Triangular plot of $\mathrm{CO}_{2}, \mathrm{H}_{2} \mathrm{~S}$, and $\mathrm{CH}_{4}$ for gas compositions from Alcedo volcano and compositions from other geothermal systems (values in mol.\%); gases from Alcedo resemble those from most geothermal systems hosted in volcanic rocks (i.e., Valles caldera, Ahuachapan, etc.). Gases from reservoirs hosted in sedimentary rocks, such as The Geysers, Cerro Prieto, Ngawha, or Sulphur Bank, contain considerably more $\mathrm{CH}_{4}$. Extremely $\mathrm{CH}_{4}$-rich or $\mathrm{CO}_{2}$-rich compositions are more typical of oil field gases and soda spring gases, respectively, but such compositions are found occasionally in geothermal regions. Data sources same as Figs. 7 and 8. (Modified from Goff and Janik 1993)

typical "mantle" values. There is a good correlation between $\delta^{34} \mathrm{~S}-\mathrm{S}_{\mathrm{T}}$ values and $\mathrm{SO}_{2} / \mathrm{H}_{2} \mathrm{~S}$ ratios for both volcanoes suggesting that the reduced sulfur in the Alcedo gases is derived by preferential removal of magmatic $\mathrm{SO}_{2}$ into the reservoir or underlying rocks (Fig. 10).

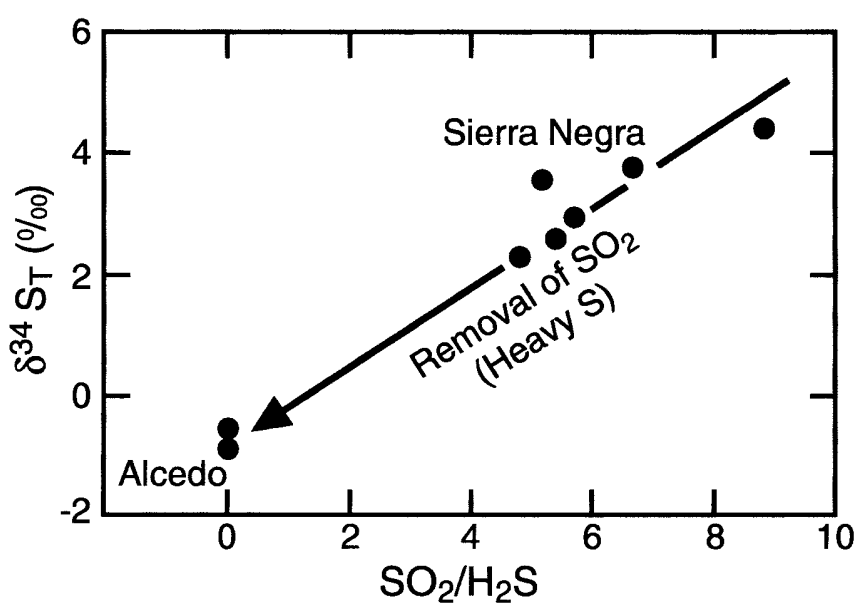

Fig. 10 Plot of $\delta^{34} \mathrm{~S}-\mathrm{S}_{\mathrm{T}}\left(\%\right.$ ) vs $\mathrm{SO}_{2} / \mathrm{H}_{2} \mathrm{~S}$ (mol ratio) for Sierra Negra and Alcedo gases. Alcedo gases could be formed from primary gases compositionally similar to those in Sierra Negra by progressive removal of $\mathrm{SO}_{2}$ during reservoir interactions. Heavy $S$ means relatively enriched in ${ }^{34} S$
Chemistry of fumarole condensates and background waters

Acid condensates from Sierra Negra fumaroles $(\mathrm{pH} \leq 1.25)$ contain high concentrations of $\mathrm{Cl}, \mathrm{F}, \mathrm{Br}$, $\mathrm{B}$, and oxidized $\mathrm{S}$ compounds $\left(\mathrm{SO}_{4}+\mathrm{SO}_{3}+\mathrm{S}_{2} \mathrm{O}_{3}\right)$ typical of volcanic condensates. Concentrations of major cations are very low (Table 5) and concentrations of some volatile and complexed trace elements are relatively high, especially $\mathrm{Ag}, \mathrm{As}, \mathrm{Cd}, \mathrm{Cu}, \mathrm{Hg}, \mathrm{I}, \mathrm{Mo}, \mathrm{Pb}$, and $\mathrm{Zn}$ (Table 6). Apparent high contents of $\mathrm{Cr}, \mathrm{Fe}$, and $\mathrm{Ni}$ may reflect some contamination from contact of acid fluid with rock fragments during the condensing process.

In contrast, fumarole condensates from Alcedo are less acidic $(\mathrm{pH} \geq 3)$. These fluids contain substantially fewer of the acid anions, particularly $\mathrm{Cl}, \mathrm{Br}, \mathrm{B}$, and $\mathrm{S}$ compounds, and contain slightly more of the major cations. In most cases trace element species are also lower in concentration relative to Sierra Negra condensates. However, the fluid condensate from Alcedo geyser is anomalous compared with other Alcedo condensates by containing considerably more $\mathrm{Ca}, \mathrm{F}, \mathrm{NH}_{4}$, and other species, possibly due to rock and clay that became mixed with the condensate during collection.

Background cold waters near the coast in the vicinity of Villamil show mixing of seawater with meteoric water. Examples include the city water supply as well (ca. 3\% seawater), and other pools and springs within $1-2 \mathrm{~km}$ of the coast. Villamil rain may contain $\geq 20 \mathrm{ppm} \mathrm{Cl}$ due to sea-spray interaction. Cold waters and rain collected further from the coast and higher in elevation contain levels of $\mathrm{Cl}$ more typical of meteoric water $(<5 \mathrm{ppm})$ and are dilute in most other components. Alcedo volcano is considerably more arid than southern Sierra Negra and no springs were found on the flanks or interior of the caldera. Instead, two pools containing evaporated rain water (and hoards of tortoises), and rain from the caldera rim, were sampled for background. Like waters from upper Sierra Negra, the Alcedo cool waters are relatively diluted in chemical character.

Chemistry of hydrothermal sulfur and explosion tephra

Selected sulfur and tephra samples were analyzed for various metals (Table 7) to help determine the source of the gases at Mina Azufral and Alcedo. Samples from Mina Azufral consisted primarily of sulfur deposits and commingled alteration products near fumaroles. Two analyses of sulfur filtered from condensate samples are also listed in Table 7. Sulfur samples from Sierra Negra tend to be relatively high in $\mathrm{As}, \mathrm{Hg}, \mathrm{Se}$, $\mathrm{Te}$, and $\mathrm{Sb}$, and contain detectable Ag. The first four elements are transported as pure elements, hydrides, and sulfides in low-temperature magmatic gases (Symonds and Reed 1993). Transport of metals is 


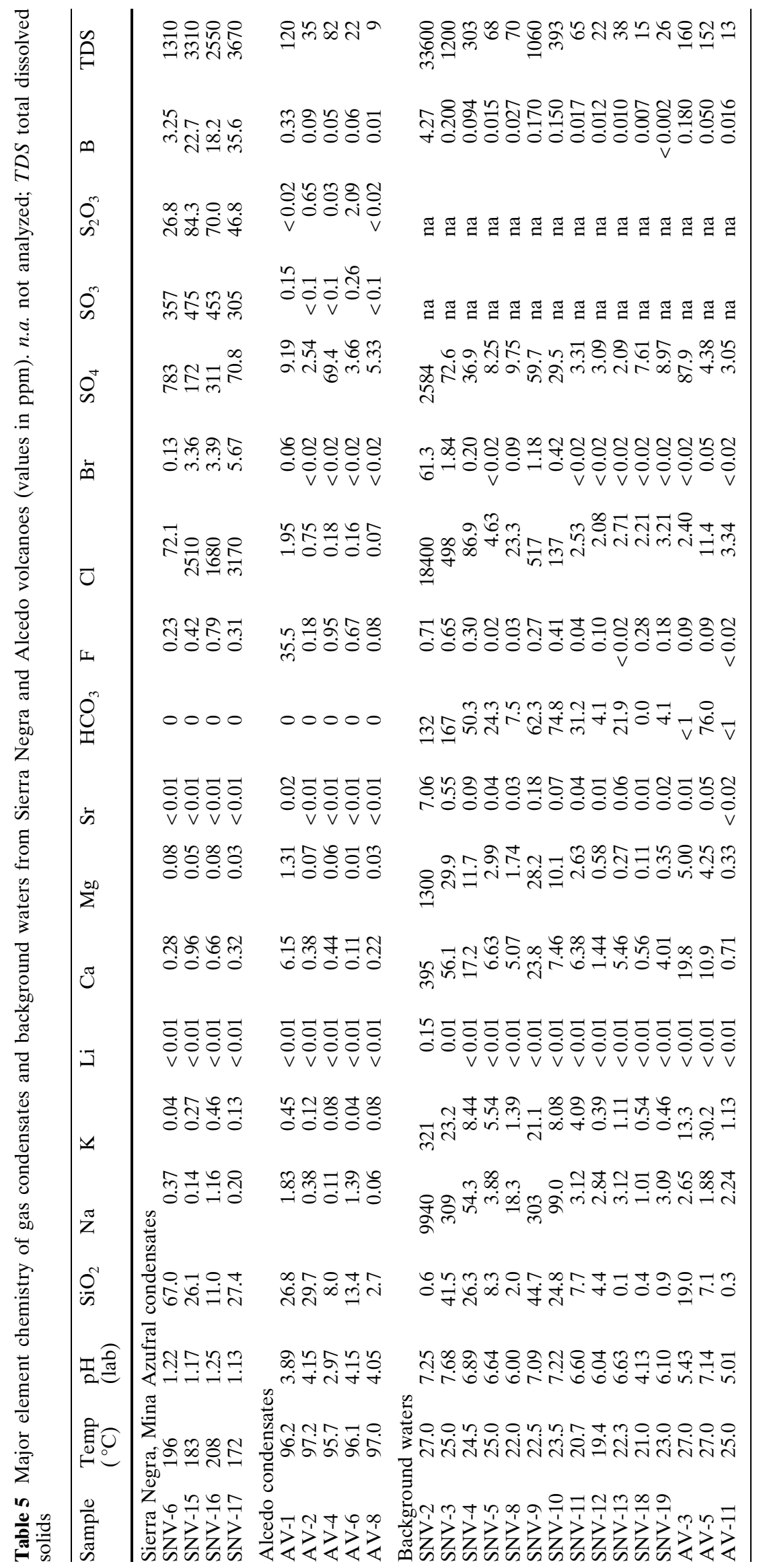

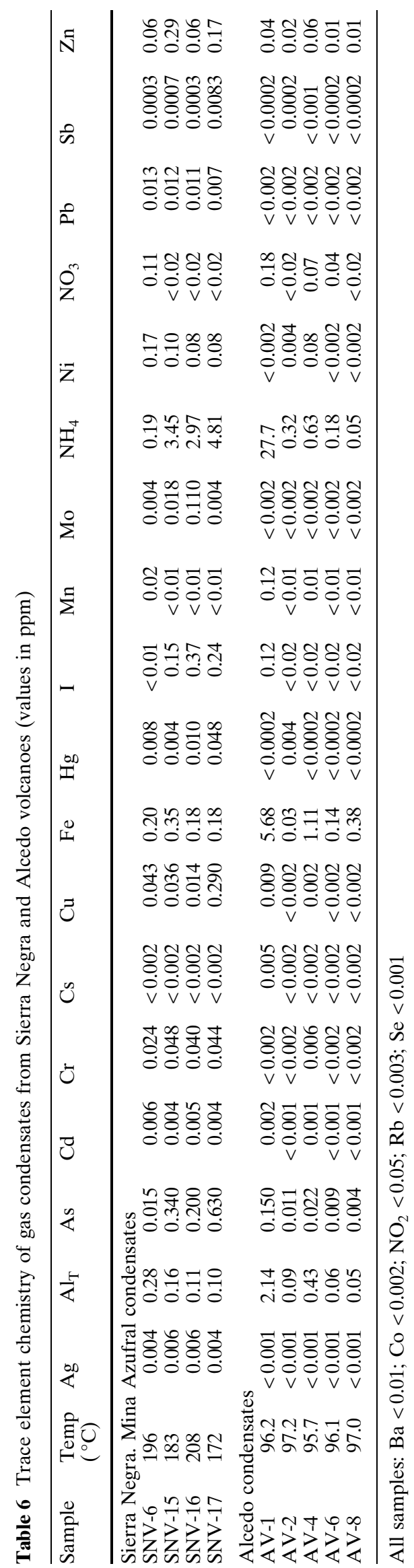


Table 7 Chemical analyses of hydrothermal deposits [analyses by D. Counce or by B. Clegg (BC), Reno, Nevada; values in ppm]

\begin{tabular}{|c|c|c|c|c|c|c|c|c|c|c|}
\hline Sample no. & Description & $\mathrm{Ag}$ & As & $\mathrm{Cu}$ & $\mathrm{Hg}$ & $\mathrm{Pb}$ & $\mathrm{Sb}$ & $\mathrm{Se}$ & $\mathrm{Te}$ & $\mathrm{Zn}$ \\
\hline \multicolumn{11}{|c|}{ Sierra Negra volcano } \\
\hline jaSNV-1 & Sulfur, $0.25 \mathrm{~g}$ & 0.12 & 16.7 & 4.1 & 0.10 & $<1$ & 0.4 & 9.8 & - & 1.1 \\
\hline jaSNV-1 (BC) & Sulfur, $100 \mathrm{~g}$ & $<0.2$ & 24 & 14 & 0.54 & $<2$ & $<5$ & - & 126 & 9 \\
\hline jaSNV-1a & Pink sulfur, $0.25 \mathrm{~g}$ & 0.09 & 1.1 & 2.6 & 0.02 & $<1$ & $<0.1$ & 3.4 & - & 0.4 \\
\hline jaSNV-3 & Sulfur, $0.25 \mathrm{~g}$ & 0.10 & 275 & 15.8 & 0.08 & 1.0 & 0.5 & 8.8 & - & 1.0 \\
\hline jaSNV-4 & Sulfur, $0.25 \mathrm{~g}$ & 0.09 & 2.5 & 4.7 & $<0.02$ & $<1$ & $<0.1$ & 1.6 & - & 1.7 \\
\hline jaSNV-5 & Sulfur, $0.25 \mathrm{~g}$ & 0.11 & 233 & 3.3 & 16.2 & $<1$ & 502 & 4.0 & - & 0.8 \\
\hline SNV-6 & Sulfur precipitation & 0.33 & 44.0 & 19.6 & 0.92 & $<4$ & 2.8 & 25.2 & - & 5.2 \\
\hline SNV-17 & Sulfur precipitation & 0.14 & 107 & 11.9 & 0.83 & 2.0 & 3.4 & 7.6 & - & 0.9 \\
\hline \multicolumn{11}{|l|}{ Alcedo Volcano } \\
\hline jaAL-3B (BC) & Hydrothermal tephra, $100 \mathrm{~g}$ & $<0.2$ & 6 & 61 & 0.14 & 9 & $<5$ & - & $<10$ & 48 \\
\hline jaAL-3C & Hydrothermal tephra, $10 \mathrm{~g}$ & 0.10 & 1.1 & 71.0 & $<0.02$ & 9.3 & 0.3 & 0.3 & - & 44.2 \\
\hline jaAL-3C (BC) & Hydrothermal tephra, $100 \mathrm{~g}$ & $<0.2$ & 7 & 69 & 0.12 & 12 & $<5$ & - & $<10$ & 52 \\
\hline jaAL-4 & Sulfur, $0.25 \mathrm{~g}$ & 0.08 & $<0.1$ & 2.6 & $<0.02$ & $<1$ & $<0.1$ & 0.3 & - & 1.2 \\
\hline jaAL-7 & Hydrothermal tephra, $10 \mathrm{~g}$ & 0.10 & 12.8 & 78.8 & 0.21 & 4.7 & 0.7 & 0.2 & - & 56.4 \\
\hline jaAL-7 (BC) & Hydrothermal tephra, $100 \mathrm{~g}$ & $<0.2$ & $<5$ & 70 & 1.10 & 6 & $<5$ & - & $<10$ & 54 \\
\hline jaAL-9 & Sulfur, $0.25 \mathrm{~g}$ & 0.11 & $<0.1$ & 4.4 & $<0.02$ & $<1$ & $<0.1$ & 0.2 & - & 0.9 \\
\hline
\end{tabular}

enhanced by acidic conditions and the presence of oxidized sulfur (as $\mathrm{SO}_{2}$ ); thus, conditions are called "high-sulfidation" (White 1991).

Samples from Alcedo consist primarily of hydrothermal explosion tephras; only two sulfur samples were analyzed. The Alcedo tephras are anomalous in $\mathrm{Cu}, \mathrm{Pb}$, and $\mathrm{Zn}$. Again, there is detectable Ag. These are elements typically enriched in liquid-dominated geothermal (epithermal or "low sulfidation") systems where reservoir conditions are near-neutral in $\mathrm{pH}$ and where sulfur is reduced (as $\mathrm{H}_{2} \mathrm{~S}$ ). Probably, the enriched levels of $\mathrm{Cu}, \mathrm{Pb}$, and $\mathrm{Zn}$ in the tephras indicate that the original rocks were in contact with reservoir fluids before the explosions occurred. Two sulfur samples from Alcedo fumaroles are chemically distinct from Mina Azufral sulfurs because they are relatively low in all analyzed metals. The differences in metal content in sulfurs between the two areas support our claim that gases at Sierra Negra originate from degassing magma, whereas the gases at Alcedo originate from boiling of hydrothermal fluids.

\section{Mixing of magmatic and meteoric fluids in basalt volcanoes}

Mixing of primary magmatic vapors with shallow meteoric waters is a common phenomenon in volcanoes and has been best documented using stable isotope and tritium analyses of the mixtures and end members (Hedenquist and Aoki 1991; Giggenbach 1992b; Shevenell and Goff 1993; Goff and McMurtry, in press). Relatively high tritium content of some mixed fluids indicates that the meteoric component is very young, in some cases $\leq 1$ year old. Figure 5 shows that this mixing can commence at relatively high temperatures for some basalt volcanoes $\left(>600^{\circ} \mathrm{C}\right)$. Much of the gas data from Kudryavy and
Momotombo volcanoes show progressive enrichments in water content that do not follow a degassing curve. In general, increasing water content correlates with decreasing temperature, and, for the 1995 Kudryavy samples, increased meteoric isotope character and increased tritium content (Goff and McMurtry, in press). This is caused by mixing of degassed primary vapor with relatively young meteoric water in the volcanic edifice.

Mixing of magmatic and meteoric components apparently takes place at much lower temperatures at the Galapagos volcanoes $\left(<300^{\circ} \mathrm{C}\right)$, probably because the relatively small intrusions beneath the horst do not release a large volume of gas. Mixing processes at Sierra Negra and Alcedo resemble those occurring at Kilauea, Hawaii. Two gas samples from Halemaumau crater, Kilauea (points $\mathrm{K} 1, \leq 310^{\circ} \mathrm{C}$ in Fig. 5), show mixing of degassed primary vapor with additional water. Stable isotope and tritium analyses show that this additional Kilauea water is relatively young meteoric water (Hinkley et al. 1995; Goff and McMurtry, in press). Sulphur Bank gas $\left(\mathrm{K} 2,96^{\circ} \mathrm{C}\right)$ is a mixture of primary vapor and a large excess of young meteoric water (Goff and McMurtry, in press). Halemaumau rim fumaroles $\left(\mathrm{K} 3,97^{\circ} \mathrm{C}\right)$ also release degassed vapor that contains relatively young meteoric water (Fig. 5). Clearly, mixing of young meteoric water and magmatic fluids is a common process at both shield and cone basalt volcanoes of any tectonic setting.

\section{Comparative hydrothermal models}

\section{Sierra Negra volcano, Mina Azufral}

Our conceptual model of hydrothermal activity in the western sector of Sierra Negra is shown in Fig. 11. It is our conclusion that relatively small basaltic magma 


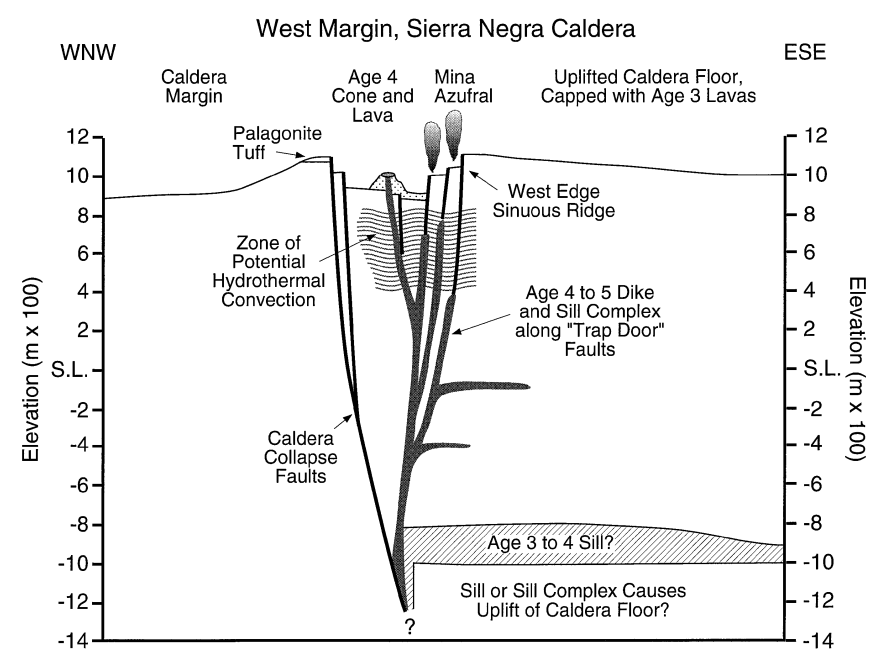

Fig. 11 Conceptual cross section of hydrothermal activity in western moat of Sierra Negra volcano, Galapagos. $\mathrm{SO}_{2}$-rich magmatic fluids degas and conductively cool from shallow basaltic magma (dikes, sills, small stock?) that may have uplifted the horst and/or injected along faults bounding the west side of the horst. Shallow meteoric waters mix with the rising magmatic fluids before they issue as relatively cool fumaroles $\left(\leq 210^{\circ} \mathrm{C}\right)$. A blind hydrothermal system may circulate at depth in the west moat of the caldera, but there is no direct evidence for existence of such a system. Vertical exaggeration is at least $4: 1$

bodies occur at relatively shallow depths in a dike and sill complex injected into the Mina Azufral faults, and that magmatic volatiles passively degas and rise along these structures. Probably, the degassing basalt is of the same age as the nearby cone ( $\leq 1000$ years?). Alternatively, there is a larger body, such as a thick sill or small stock, that has uplifted the horst and has provided a long-term source of volatiles. The heat from these comparatively small intrusions may have created a "blind" geothermal system in the western moat, but no surface evidence, such as hot springs and/or $\mathrm{H}_{2} \mathrm{~S}$-rich fumaroles, is visible to verify the existence of such a system.

Reynolds et al. (1995) claim that $90 \%$ of the surface of Sierra Negra is covered with eruptive products $\leq 5700$ years old. They subdivide the eruptions into five age groups (Age 1 is oldest, Age 5 is youngest). According to Reynolds and co-workers, the floor of the caldera and the flows capping the central horst are Age 3, whereas the scattered cones and flows in the western moat are Age 4. The Age 4 flows adjacent to Mina Azufral are relatively unfaulted; thus, these more recent eruptions occurred after most of the uplift of the horst. Although Colony and Nordlie (1973) indicate that fumarolic activity at Mina Azufral and uplift of the horst coincide in time, the sharp fault scarps and benches argue that most of the uplift began before fumarolic activity began or that uplift was extremely rapid and recent.

Nordlie (1973) and Reynolds et al. (1995) have discussed several ideas on the structural collapse of the caldera and growth of the central horst. The uplifted block has morphological similarities to resurgent (structural) domes found in many silicic calderas (Smith and Bailey 1968). Uplift of these central domes is usually caused by tumescence of magma $\leq 7 \mathrm{~km}$ deep. Many are asymmetric or "trap door" in form. By analogy, relatively shallow injection of basaltic magma provides an explanation for uplift and creation of faults that later act as major pathways for younger intrusion and volatile release.

Although we observed no cold springs or standing pools of water in the western moat, Reynolds et al. (1995) found beds of Age 3 palagonite tuff on the west caldera rim. These beds provide convincing evidence that an intracaldera lake or abundant shallow groundwater once existed in the western caldera and interacted with magma during an eruption. The present rainfall is probably more than sufficient to recharge the western moat. However, the small inferred size and youth of the basaltic dike system has not provided enough heat to sustain vigorous hydrothermal convection in the Sierra Negra caldera. The faults in this zone provide relatively free passage for gases to reach the surface.

\section{Alcedo volcano}

The conceptual model for Alcedo (Fig. 12) has some fundamental differences from our Sierra Negra model.

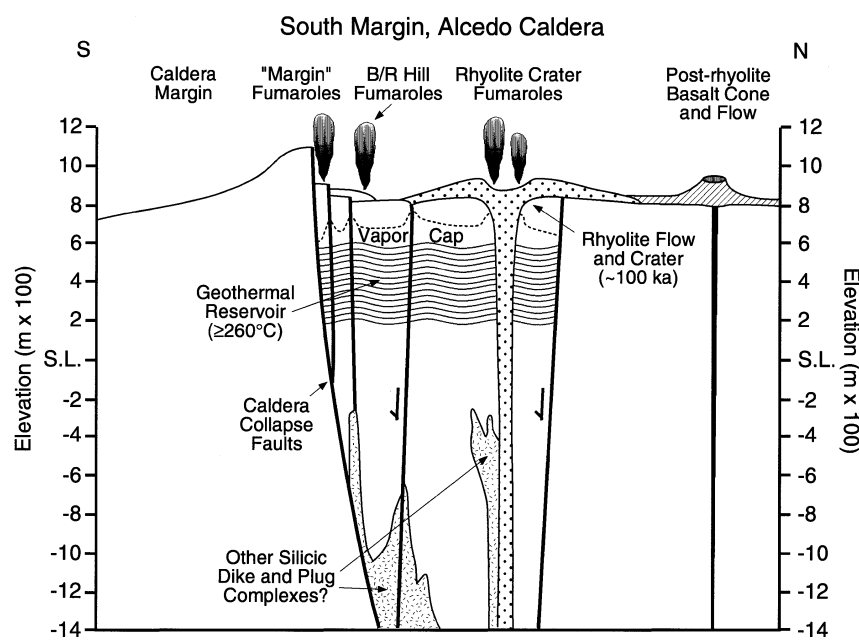

Fig. 12 Conceptual cross section of hydrothermal activity in southern sector of Alcedo volcano, Galapagos. Relatively $\mathrm{H}_{2} \mathrm{~S}$ rich fumaroles at typical boiling temperatures $\left(\leq 98^{\circ} \mathrm{C}\right)$ occur throughout a widespread area and indicate presence of underlying liquid-dominated reservoir. Gas geothermometry indicates reservoir temperature of $\geq 260^{\circ} \mathrm{C}$. The liquid reservoir is overlain by a vapor-rich cap. Reservoir fluid is composed primarily of local meteoric water infiltrating the caldera but also contains degassed magmatic components from shallow, compound rhyolitic intrusions (Geist et al. 1994, 1995). Permeability is enhanced by caldera-related faults and by explosive and effusive rhyolitic events. Basaltic eruptions post-dating the rhyolites may contribute additional heat and magmatic volatiles to the system. Vertical exaggeration is at least $4: 1$ 
A geothermal reservoir of $\geq 260^{\circ} \mathrm{C}$ underlies the entire SW sector of the caldera and has formed widespread fumaroles and phreatic explosion craters. Steam is released along obvious faults and from a rhyolitic crater vent. Groundwater accumulating in the caldera depression has been heated by a relatively large volume of shallow, silicic magma for a considerably longer time than at Sierra Negra. Alcedo has petrologic and tectonic similarities to Krafla volcano, Iceland, which also hosts a geothermal system (Jonasson 1994).

According to Geist et al. (1994) the Alcedo rhyolites, dated by $\mathrm{K}-\mathrm{Ar}$ methods, are approximately 140 to $74 \mathrm{ka}$. The total volume of rhyolite erupted from the caldera flank, rim, and interior is at least $0.7 \mathrm{~km}^{3}$. The magmatic roots of these rhyolites provide a vigorous heat source that induces hydrothermal circulation of meteoric waters infiltrating the caldera depression. Additional heat may be contributed by 10-20 basalt eruptions that post-date the rhyolites, but this heat source is considered minor compared with the rhyolitic intrusions. The reservoir may circulate as deep as $1000 \mathrm{~m}$ (the depth to the boiling point for pure water at $300^{\circ} \mathrm{C}$ is $1085 \mathrm{~m}$ ). Rapid upflow of fluids along faults is accompanied by intensive boiling at $120-220^{\circ} \mathrm{C}$ as indicated by the stable isotope data. Using the boiling point curve, this boiling occurs at depths ranging from 250 to as little as $10 \mathrm{~m}$.

The presence of so many aligned explosion craters indicates that the rocks and their faults cannot transport steam to the surface as fast as it is produced. Local sealing causes over-pressured conditions until lithostatic pressure is exceeded by vapor pressure and explosions occur. Explosions could be facilitated by small earthquakes such as those felt by previous visitors.

Although magmatic carbon, sulfur, chlorine, and helium are contributed to the reservoir, acidic components are no doubt neutralized by reactions with rock and then extensively diluted with meteoric water. The Alcedo reservoir is probably a liquid-dominated hydrothermal system with neutral-chloride fluid (similar to most geothermal systems in volcanic environments), which boils to produce a vapor-rich cap.

The thermal power released by Chantel and Laura fumaroles is calculated as follows: We visually estimated the flux of steam released by both fumaroles at $15 \mathrm{~m}^{3} / \mathrm{s}$. Since the enthalpy and density of steam at $100{ }^{\circ} \mathrm{C}$ is $2676 \mathrm{~J} / \mathrm{g}$ and $5.98 \times 10^{-4} \mathrm{~g} / \mathrm{cm}^{3}$, respectively, the estimated power output is approximately $24 \mathrm{MW}$ from these two fumaroles. However, the reservoir in Alcedo is probably $\geq 260^{\circ} \mathrm{C}$, so it is reasonable to assume that the reservoir could produce much hotter two-phase fluid if exploited by wells.

If an equivalent volume $\left(15 \mathrm{~m}^{3} / \mathrm{s}\right)$ of flashed steam is generated from geothermal wells at a separation temperature of $180^{\circ} \mathrm{C}$ (a fairly typical temperature), the calculated power is approximately $215 \mathrm{MW}$. If the conversion efficiency to electric power is $10 \%$, this is equivalent to approximately $22 \mathrm{MW}$. Considering the size of the geothermal anomaly in Alcedo (at least $1 \times 4 \mathrm{~km}$ ), it is very likely that this resource could generate nearly $150 \mathrm{MW}$.

\section{Conclusion}

Fumarole gases at Sierra Negra and Alcedo shield volcanoes display contrasting physical appearance and geochemical composition that indicate differences in volcanic, structural, and hydrothermal evolution. Despite their differences, both volcanoes release helium, carbon, sulfur, and other components of mantle/ magmatic origin.

Gases at Mina Azufral, Sierra Negra, are passively released by basaltic intrusions $\leq 5 \mathrm{~km}$ deep that underlie the western segment of an intracaldera horst. The general appearance of this restricted fumarole area has not changed for over 100 years indicating that the source magma and configuration of faults has remained relatively unchanged. Because fumarole temperatures exceed $200^{\circ} \mathrm{C}$ and sulfur is released dominantly as $\mathrm{SO}_{2}$, the majority of acidic components can only come from shallow decompression of magma. The magmatic gases mix with shallow meteoric waters before emerging at the surface.

In contrast, fumarole gases in Alcedo volcano are released during boiling of a widespread hydrothermal system consisting of a mixture of meteoric water and magmatic gases that is heated by shallow rhyolitic intrusions in the southwestern caldera. Fumarole temperatures do not exceed $98^{\circ} \mathrm{C}$ and the sulfur is primarily reduced as $\mathrm{H}_{2} \mathrm{~S}$. Ascending gases are primarily controlled by a caldera-margin fault over $4 \mathrm{~km}$ long. Recent hydrothermal explosions and tree kills along this fault imply dynamic changes in the reservoir at time scales of less than a few years. Earthquakes and explosions can be felt and heard by those who enter the caldera. More than likely, the Alcedo reservoir consists of a relatively thin vapor-rich cap overlying a liquid-dominated system containing neutral-chloriderich fluids.

Electric power production from the Alcedo geothermal system would have many obstacles to development, not the least of which is the National Park status of the Galapagos and the rare animals and plants that reside around and within the caldera of this volcano. Commercial development would also detract from the wild and scenic beauty of the landscape. From a practical standpoint, surface water is in such scarce supply that water for drilling operations and potable uses does not exist. There is no infrastructure to transport workers and equipment and keep them supplied. In addition, there is no population or industry on Isabela Island that can use the power, nor are there lines to export the power. However, a viable geothermal resource apparently exists in Alcedo that could be developed if the aforementioned obstacles are responsibly addressed. 
Acknowledgements The authors thank L. Chellis and C. Blanton (formerly of Estacion Cientifica Charles Darwin), A. Izurieta (Parque Nacional Galapagos), and G. Cerón (Fundacion Charles Darwin) for overall logistical support in the Galapagos. R. Andrade (ECCD) and A. Tupiza (PNG) provided direct assistance at Sierra Negra. D. Geist (Univ Idaho, Moscow, Idaho) gave many valuable suggestions on successful field operations at these relatively remote locations. L. LeMarie (Escuela Politecnica Nacional, Quito) lent us extra Ti-tubing for those deep fumaroles at Mina Azufral. C. Werner (now at Penn State University) plotted much of our data. M.C. van Soest (Vrije University) helped with noble gas analyses. The manuscript was greatly improved after perceptive reviews by $D$. Bergfeld (LANL), C.J. Janik (USGS), T. Fischer (LBNL), and R. Symonds (USGS). This project was funded by an LDRD grant (Magmatic Tritium) from Los Alamos National Laboratory. This is SOEST contribution no. 4905 .

\section{References}

Colony WE, Nordlie BE (1973) Liquid sulfur at Volcano Azufre, Galapagos Islands. Econ Geol 68:371-380

Craig H (1961) Isotopic variations in meteoric waters. Science $133: 1702-1703$

Craig H, Gordon L, Horibe Y (1963) Isotope exchange effects in the evaporation of water. J Geophys Res 68:5079-5083

D'Amore F, Panichi C (1980) Evaluation of deep temperatures of hydrothermal systems by a new gas geothermometer. Geochim Cosmochim Acta 44:549-556

Delaney JR, Colony WE, Gerlach TM, Nordlie BE (1973) Geology of the Volcan Chico area on Sierra Negra volcano, Galapagos Islands. Geol Soc Am Bull 84:2455-2470

Dugan JP, Borthwick J, Harmon RS, Gagnier MA, Glahn JE, Kinsel EP, MacLeod S, Viglino JA, Hess JW (1985) Guanidine hydrochloride method for determination of water oxygen isotope ratios and the oxygen-18 fractionation between carbon dioxide and water at $25^{\circ} \mathrm{C}$. Anal Chem 57:1734-1736

Fahlquist L, Janik CJ (1992) Procedures for collecting and analyzing gas samples from geothermal systems. US Geol Surv Open-File Rep 92-211:1-19

Farley KA, Neroda E (1998) Noble gases in the Earth's mantle. Ann Rev Earth Planet Sci 26:189-218

Fischer T, Giggenbach W, Sano Y, Williams S (1998) Fluxes and sources of volatiles discharged from Kudryavy, a subduction zone volcano, Kurile Islands. Earth Planet Sci Lett $160: 81-96$

Geist D, Howard KA, Jellinek AM, Rayder S (1994) The volcanic history of Volcan Alcedo, Galapagos Archipelago: a case study of rhyolitic oceanic volcanism. Bull Volcanol $56: 243-260$

Geist D, Howard KA, Larson P (1995) The generation of oceanic rhyolites by crystal fractionation: the basalt-rhyolite association at Volcan Alcedo, Galapagos archipelago. J Petrol 36:965-982

Giggenbach WF (1992a) Isotopic shifts in waters from geothermal and volcanic systems along convergent plate boundaries and their origin. Earth Planet Sci Lett 113:495-510

Giggenbach WF (1992b) Chemical techniques in geothermal exploration. UNITAR/UNDP, Rome, Italy, pp 119-144

Giggenbach WF (1996) Chemical composition of volcanic gases. In: Scarpa R, Tilling RI (eds) Monitoring and mitigation of volcano hazards. Springer, Berlin Heidelberg New York, pp 221-256

Giggenbach WF, Lyon G (1977) The chemical and isotopic composition of water and gas discharges. Dept Sci Indus Res Rep CD 2401, Petone, New Zealand, pp 69-81

Giggenbach WF, Matsuo S (1991) Evaluation of results from second and third IAVCEI field workshops on volcanic gases, Mt. Usu, Japan and White Island, New Zealand. Appl Geochem $6: 125-141$
Goff F, Gardner JN (1994) Evolution of a mineralized geothermal system, Valles caldera, New Mexico. Econ Geol 89: 1803-1821

Goff F, Janik CJ (1993) Gas geochemistry and guide for geothermal features in the Clear Lake region, California. In: Rytuba JJ (ed) Active geothermal systems and gold-mercury deposits in the Sonoma-Clear Lake volcanic fields, California. Soc Econ Geol Guidebook Ser 16:207-261

Goff F, McMurtry GM (in press) Tritium and stable isotopes of magmatic waters. J Volcanol Geotherm Res

Graham DW, Christie DM, Harpp KS, Lupton JE (1993) Mantle plume helium in submarine basalts from the Galapagos platform. Science 262:2023-2026

Green JA (1994) Recent activity in Alcedo volcano, Isabela Island. Noticias Galapagos 54:11-12

Greenland LP (1984) Gas composition of the January 1983 eruption of Kilauea Volcano, Hawaii. Geochim Cosmochim Acta 48:193-195

Hedenquist JW, Aoki M (1991) Meteoric interaction with magmatic discharges in Japan and the significance for mineralization. Geology 19:1041-1044

Henley RW, Truesdell AH, Barton PB, Whitney JA (1984) Fluid-mineral equilibria in hydrothermal systems. Rev Econ Geol 11:1-267

Hey R, Johnson GL, Lowrie A (1977) Recent plate motions in the Galapagos area. Geol Soc Am Bull 88:1385-1401

Hilton DR, McMurtry GM, Kreulen R (1997) Evidence for extensive degassing of the Hawaiian mantle plume from helium-carbon relationships at Kilauea Volcano. Geophys Res Lett $24: 3065-3068$

Hilton D, McMurtry G, Goff F (1998) Large variations in vent fluid $\mathrm{CO}_{2}{ }^{3} \mathrm{He}$ ratios signal rapid changes in magma chemistry at Loihi seamount, Hawaii. Nature 396:359-362

Hinkley TK, Quick JE, Gregory RT, Gerlach TM (1995) Hydrogen and oxygen isotopic compositions of waters from fumaroles at Kilauea summit, Hawaii. Bull Volcanol 57: 44-51

Janik CJ, Nehring N, Huebner M, Truesdell AH (1982) Carbon-13 variations in fluids from the Cerro Prieto geothermal system. Proc 4th Symp Cerro Prieto Geotherm. Field, Guadalajara, Mexico, vol 2, 7 pp

Janik CJ, Goff F, Fahlquist L, Adams A, Roldan A, Trujillo P, Counce D, Chipera S (1992) Hydrogeochemical exploration of geothermal prospects in the Tecuamburro volcano region, Guatemala. Geothermics 21:447-481

Jonasson K (1994) Rhyolite volcanism in the Krafla central volcano, northeast Iceland. Bull Volcanol 56:516-528

Lowenstern J, Janik CJ, Fournier RO, Tesfai T, Duffield W, Clynne M, Smith M, Woldegiorgis L, Weldemariam K, Kahsai G (1999) A geochemical reconnaissance of the Alid volcanic center and geothermal system, Danakil depression, Eritrea. Geothermics 28:161-187

Marty B, Meyner V, Nicolini E, Griesshaber E, Toutain JP (1993) Geochemistry of gas emanations: a case study of the Reunion hot spot, Indian Ocean. Appl Geochem 8:141-152

McBirney AR, Cullen AB, Geist D, Vincent EP, Duncan RA Hall ML, Estrella M (1985) The Galapagos Volcano Alcedo: a unique ocean caldera. $J$ Volcanol Geotherm Res $26: 173-177$

Nordlie BE (1973) Morphology and structure of the western Galapagos volcanoes and a model for their structure. Geol Soc Am Bull 84:2931-2956

Nordlie BE, Colony WE (1973) Fumarole with periodic water fountaining, Volcan Alcedo, Galapagos Islands. Geol Soc Am Bull 84:1709-1720

Norman D, Bernhardt C (1981) Assessment of geothermal reservoirs by analysis of gases in thermal waters. Final Tech Rep, New Mexico Energy Institute, New Mexico State University, Las Cruces, $130 \mathrm{pp}$

Ostlund HG, Dorsey HG, Rooth CG (1974) GEOSECS North Atlantic radiocarbon and tritium results. Earth Planet Sci Lett $23: 69-86$ 
Poreda R, Craig H (1989) Helium isotope ratios in circum-Pacific volcanic areas. Nature 338:473-478

Reynolds R, Geist DJ, Kurz MD (1995) Physical volcanology and structural development of Sierra Negra, Isabella Island, Galapagos archipelago. Geol Soc Am Bull 107:1398-1410

Rollison H (1993) Using geochemical data: evaluation, presentation, interpretation. Wiley, New York

Sakai H, Casadevall T, Moore JG (1982) Chemistry and isotope ratios of sulfur in basalts and volcanic gases at Kilauea volcano, Hawaii. Geochim Cosmochim Acta 46:729-738

Shevenell L, Goff F (1993) Addition of magmatic volatiles into the hot spring waters of Loowit Canyon, Mount St. Helens, Washington, USA. Bull Volcanol 55:489-503

Shevenell L, Goff F (1995) The use of tritium in groundwater to determine fluid mean residence times of Valles caldera hydrothermal fluids, New Mexico, USA. J Volcanol Geotherm Res $67: 187-205$

Simkin T (1984) Geology of the Galapagos Islands. In: Perry R (ed) Key environments Galapagos. Pergamon Press, Oxford, pp 15-41

Simkin T, Seibert L, McClelland L, Bridge D, Newhall C, Latter J (1981) Volcanoes of the World. Hutchison, Ross, Straudsburg, Pennsylvania

Smith RL, Bailey RA (1968) Resurgent cauldrons. Geol Soc Am Mem 116:613-662

Smith SP, Kennedy BM (1985) Noble gas evidence for two fluids in the Baca (Valles Caldera) geothermal reservoir. Geochim Cosmochim Acta 49:893-902
Symonds R, Reed M (1993) Calculation of multicomponent chemical equilibria in gas-solid-liquid systems: calculation methods, thermochemical data, and applications to studies of high-temperature volcanic gases with examples from Mount St. Helens. Am J Sci 293 : 758-864

Taran Y, Hedenquist J, Korzhinsky M, Tkachenko S, Shmulovich K (1995) Geochemistry of magmatic gases from Kudryavy volcano, Iturup, Kuril Islands. Geochim Cosmochim Acta 59:1749-1761

Trujillo P, Counce D, Grigsby C, Goff F, Shevenell L (1987) Chemical analysis and sampling techniques for geothermal fluids and gases at the Fenton Hill laboratory. Los Alamos National Lab Rept LA-11006-MS, 84 pp

Van Soest MC, Hilton DR, Kreulen R (1998) Tracing crustal and slab contributions to arc magmatism in the Lesser Antilles island arc using helium and carbon relationships in geothermal fluids. Geochim Cosmochim Acta 62:3323-3335

Vuataz FD, Goff F (1986) Isotope geochemistry of thermal and nonthermal waters in the Valles caldera, Jemez Mountains, northern New Mexico. J Geophys Res 91:1835-1853

White NC (1991) High sulfidation epithermal gold deposits: characteristics and a model for their origin. Geol Surv Japan Rept 277:9-20

White WM, McBirney AR, Duncan RA (1993) Petrology of the Galapagos Islands: portrait of a pathological mantle plume. J Geophys Res 98:533-563 